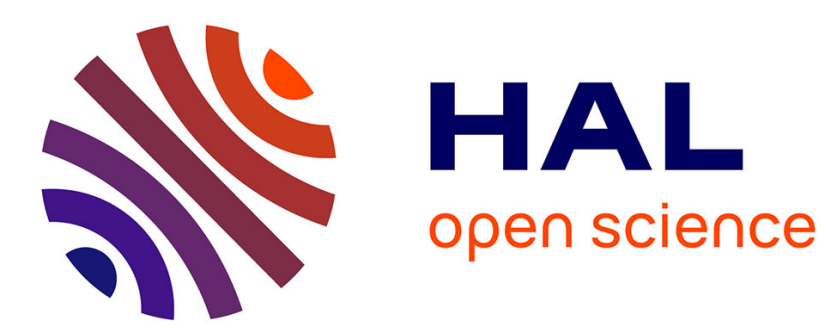

\title{
Do banks differently set their liquidity ratios based on their network characteristics?
}

Isabelle Distinguin, Aref Mahdavi-Ardekani, Amine Tarazi

\section{To cite this version:}

Isabelle Distinguin, Aref Mahdavi-Ardekani, Amine Tarazi. Do banks differently set their liquidity ratios based on their network characteristics? . 2017. hal-01336784v3

\section{HAL Id: hal-01336784 \\ https: / hal-unilim.archives-ouvertes.fr/hal-01336784v3}

Preprint submitted on 22 Mar 2017

HAL is a multi-disciplinary open access archive for the deposit and dissemination of scientific research documents, whether they are published or not. The documents may come from teaching and research institutions in France or abroad, or from public or private research centers.
L'archive ouverte pluridisciplinaire HAL, est destinée au dépôt et à la diffusion de documents scientifiques de niveau recherche, publiés ou non, émanant des établissements d'enseignement et de recherche français ou étrangers, des laboratoires publics ou privés. 


\title{
Do banks differently set their liquidity ratios based on their network characteristics?
}

\author{
Isabelle Distinguin ${ }^{*}$, Aref Mahdavi-Ardekani ${ }^{\dagger *}$, Amine Tarazi* \\ *Université de Limoges, LAPE, 5 rue Félix Eboué, 87031 Limoges, France
}

This Draft: December 3, 2016

Please do not quote without the permission of the authors

\begin{abstract}
This paper investigates the impact of interbank network topology on bank liquidity ratios. Whereas more emphasis has been put on liquidity requirements by regulators since the global financial crisis of 2007-2008, how differently shaped interbank networks impact individual bank liquidity behavior remains an open issue. We look at how bank interconnectedness within interbank loan and deposit networks affects their decision to hold more or less liquidity during normal times and distress times and depending on the overall size of the banking sector. Our sample consists of commercial, investment, real estate and mortgage banks established in 28 European countries. We conduct instrumental variable estimations to examine the relationship between interbank network topology and bank liquidity. Our results show that taking into account the way that banks are linked to each other within a network adds value to traditional liquidity models. Our findings have critical implications with regards to the implementation of Basel III liquidity requirements and bank supervision more generally.
\end{abstract}

JEL Classification: G01, G32, G21 and G28

Keywords: Interbank network topology, Basel III, Liquidity risk, Financial Crisis

\footnotetext{
${ }^{\dagger}$ Corresponding author. Tel: +33555149251

*Email Address: isabelle.distinguin@unilim.fr (I. Distinguin), aref.mahdavi@ unilim.fr (A. Mahdavi-Ardekani), amine.tarazi@unilim.fr (A. Tarazi),
} 


\title{
Do banks differently set their liquidity ratios based on their network characteristics?
}

\section{This Draft: December 3, 2016}

Please do not quote without the permission of the authors

\begin{abstract}
This paper investigates the impact of interbank network topology on bank liquidity ratios. Whereas more emphasis has been put on liquidity requirements by regulators since the global financial crisis of 2007-2008, how differently shaped interbank networks impact individual bank liquidity behavior remains an open issue. We look at how bank interconnectedness within interbank loan and deposit networks affects their decision to hold more or less liquidity during normal times and distress times and depending on the overall size of the banking sector. Our sample consists of commercial, investment, real estate and mortgage banks established in 28 European countries. We conduct instrumental variable estimations to examine the relationship between interbank network topology and bank liquidity. Our results show that taking into account the way that banks are linked to each other within a network adds value to traditional liquidity models. Our findings have critical implications with regards to the implementation of Basel III liquidity requirements and bank supervision more generally. JEL Classification: G01, G32, G21 and G28

Keywords: Interbank network topology, Basel III, Liquidity risk, Financial Crisis
\end{abstract}




\section{Introduction}

One of the most prominent functions of banks in the economy is liquidity creation, which in turn makes them inherently vulnerable (Diamond \& Dybvig, 1983). Because they face liquidity shortages or surpluses in their daily operations, banks and other financial institutions are interconnected in different ways based on distinct bilateral transactions on the interbank market. Such linkages enable efficient risk management and risk transfer but are also a potential source of contagion and systemic risk. The global financial crisis of 2007-2008 has led bank regulators to impose new liquidity requirements to supplement the already existing minimum capital ratios. Under the new framework (Basel III), banks have to comply with standard minimum liquidity ratios independently of their network characteristics. Recent studies such as Glasserman \& Young (2015); Huang et al. (2016); Paltalidis et al. (2015) and Souza et al. (2015) have however pointed the significant role played by the shape of interbank network connectedness in systemic risk and the contagion of financial shocks to the economy as a whole. In this paper, we investigate how bank interconnectedness within interbank loan and deposit networks affects their decision to hold more or less liquidity during normal times and distress times and depending on the overall size of the banking sector.

Empirical studies on interbank networks have either focused on dynamic or static network analysis of interbank markets. On the one hand, dynamic approaches have highlighted the fragility of the financial system by showing how the propagation of financial shocks and individual bank defaults could lead to the failure of other institutions and eventually to the collapse of the entire financial system (Caccioli et al. 2014; Dungey \& Gajurel, 2015; FryMcKibbin et al. 2014; and Souza et al. 2016). On the other hand, static approaches shed light on the importance of the state of interbank connectedness, called network topology, determining specific and group characteristics of distinctive financial networks (Craig \& Von Peter, 2014; González-Avella et al. 2016; Veld \& Van Lelyveld, 2014; Langfield et al. 2014). In our work we follow the latter literature on network topology which enables to draw a clear picture of the increasing complexity of interbank connections and interdependencies. Several studies have used such network topology statistics and examined how these statistics contribute to representing a more precise picture of the whole system. Martinez-Jaramillo, Alexandrova-Kabadjova, BravoBenitez, \& Solórzano-Margain (2014) and Rørdam \& Bech (2009) compare the topologies of 
interbank exposure networks in different countries as well as those of payment flow networks and draw different topological characteristics of both mentioned networks. Iori et al. (2008); Kuzubaş et al. (2014) and Soramäki et al) assess the network topology of payment systems in different countries to analyze the efficiency of the interbank market and the contribution of each bank to system stability. Also, Chinazzi et al. (2013) and Soramäki et al. (2007) show that small and large banks are more willing to interact with each other in the interbank network than banks of the same size.

The liquidity standards introduced by the Basel Committee after the global financial crisis of 2007-2008 (BIS, 2010) require banks to hold a sufficient amount of high-quality liquid assets to protect them from liquidity shocks over a one month horizon (Liquidity Coverage Ratio, LCR) and to maintain sufficient stable funds over a one-year horizon (Net Stable Funding Ratio, NSFR). However, the minimum requirements are independent of the topology and characteristics of the network in which banks operate. Banks might in fact target different liquidity ratios or adjust differently depending on their position and interconnectedness on the interbank loan and deposit market. Furthermore, banks obviously target different ratios during normal times and distress periods, which could also be differently shaped depending on their position.

Consistent with the new regulatory standards, recent studies have shown the importance of holding sufficient liquidity during crisis periods. Chiaramonte \& Casu (2015) and Gobat et al. show that excessive maturity transformation was a significant source of bank instability during the global financial crisis of 2007-2008. Also, Gobat et al. (2014) find that banks with a lower NSFR ratio were more likely to face a run and fail during the global financial crisis even when their capital ratio was above the minimum required level. Vazquez \& Federico (2015) examine the relationship between the NSFR ratio and leverage in bank balance sheets during the same crisis and find that banks with a lower NSFR ratio and stronger leverage ratio were more likely to fail. Such weaknesses were furthermore observed during the European sovereign debt crisis of 2010-2011. Commercial interbank loans sharply shrank revealing a dramatic loss of confidence and severally tightened banks' liquidity positions. Moreover, this loss of confidence lead European banks to substitute central bank operations to interbank operations increasing their reliance on the European central bank (ECB). One significant consequence of this change is the 
collateral squeeze imposed to borrowing banks thereby reducing the amount of loans they could grant. Furthermore, pressured by the market, banks have shown an effort to quickly adjust to the new Basel III liquidity requirements as soon as they were announced in 2010 although compliance is gradual and full implementation was planned for 2017 (Allen \& Moessner, 2012).

We work on a sample of 1328 banks from 28 European countries encompassing an integrated area under the supervision of a unique monetary authority (ECB). Such an environment is expected to facilitate transactions among participating countries but also to more easily trigger global instability during severe financial distress periods. European banks have experienced both the global financial crisis of 2007-2008 and the sovereign debt crisis of 20102011, which provides us with an interesting laboratory to investigate the reaction of banks within distinct interbank network topologies during two different financial meltdowns.

By focusing on the static network analysis approach, we contribute to the literature by examining how individual and system-wide bank connectedness affects liquidity management and liquidity ratios of individual banks and whether such ratios are strongly dependent on the shape of networks throughout European countries. Although there is an extensive banking literature examining the determinants of bank liquidity (Cucinelli, 2013; Distinguin et al. 2013; King, 2013; Mattana \& Panetti, 2014; Roman \& Şargu, 2014; Vodová, 2011), existing studies have neglected the role of interconnectedness among banks in interbank networks. For consistency with the new regulatory framework, we examine the relationship between interbank network topology and the NSFR ratio. Nevertheless, we also consider the other liquidity ratios used in the banking literature. We bridge the gap between two different strands of the literature and examine how different states of connectedness, which are determined by the topology of the interbank network, influences banks' balance sheet liquidity. We use simulated interbank networks to compute various network statistics such as In-degree, Out-degree, Betweenness Centrality, Closeness centrality, Hub, Authority, Pagerank and Clustering coefficient that are in turn introduced as additional variables to augment traditional bank liquidity models. We hence add to the literature by investigating the additional explanatory power of such so far neglected variables.

Our results show that banks with higher degree of outflow (total number of borrowers) and lower degree of inflow (total number of lenders) connections, as well as banks with a higher 
triangular interconnectedness on the interbank market, set a higher liquidity ratio. Conversely, banks with higher system-wide position in the interbank network set a lower liquidity ratio. Besides, during crisis times, banks set their liquidity ratio based on their position throughout the network and less on their local position on the interbank market, highlighting fragility of interbank markets during such periods.

Furthermore, banks with a significant direct interbank position in large banking systems exhibit higher ratios than in smaller ones suggesting a possible more prudent management to avoid liquidity shortage and propagation of liquidity shocks. Likewise, banks that are connected to highly interconnected banks in small networks are more confident to fund their assets with short-term interbank debt instead of stable funds.

The rest of the paper is laid out as follows. Section 2 describes the data, variables and methodology, while section 3 presents the results of our study. Robustness checks are reported in section 4. Section 5 concludes.

\section{Sample, variables and method}

\subsection{Sample}

Our sample consists of commercial, investment, real estate and mortgage banks established in 28 European countries ${ }^{1}$. We omit savings, mutual and cooperative banks due to their specificities in terms of interbank relationships. Indeed, they transact mainly with the central institutions of their own system (Boss \& Elsinger, 2004; BIS, 2001; Worms, 2001). The sample period runs from 2001 to 2013. Accounting data (annual financial statements) for individual banks are obtained from Bankscope Fitch IBCA. Bankscope reported balance sheets and income statements for 1714 banks for the countries we consider in this study. After eliminating banks for which Bankscope does not report information on our variables of interest, our final sample of banks consists of 1328 banks. More than $75 \%$ are commercial banks, around $15 \%$ are real estate and mortgage banks and less than $10 \%$ are investment banks.

\footnotetext{
${ }^{1}$ Austria, Belgium, Bulgaria, Croatia, Cyprus, Czech Republic, Denmark, Estonia, Finland, France, Germany, Greece, Hungary, Ireland, Italy, Latvia, Lithuania, Luxembourg, Malta, Netherlands, Poland, Portugal, Romania, Slovakia, Slovenia, Spain, Sweden and the United Kingdom.
} 
Table A1 in appendix shows some descriptive statistics for the raw sample of 1714 banks and the final sample of banks we use. The univariate statistics of these two samples are very similar and on average, the final sample of banks (Table 1) represents more than $88 \%$ of the total assets of commercial, investment, real estate and mortgage banks covered by Bankscope for the different sample countries (the lowest is $74.62 \%$ for the Netherlands and the highest is $98.45 \%$ for Denmark).

\section{[Insert Table 1]}

\subsection{Definition of variables}

We present our dependent variable, the different independent variables reflecting interbank network and the other control variables introduced in our estimations. Descriptive statistics regarding these variables are provided in Table 2. We have winsorized extreme bank year observations for our dependent and bank-level control variables (5\% lowest and highest values).

[Insert Table 2]

\subsubsection{Structural Liquidity indicator (NSFR)}

The Basel Committee on Banking Regulation and Supervision developed an international framework for liquidity assessment in banking including the implementation of the "net stable funding ratio" (BIS, 2009). It encourages banks to finance their illiquid assets with more stable and less risky funds and consequently reduces liquidity mismatch. It is a structural tool for liquidity measurement as it considers both sides of the balance sheet and categorizes assets and liabilities as liquid, semi-liquid and illiquid and assigns weights to each component This ratio is defined in BIS (2010) as:

$N S F R=\frac{\text { Available amount of stable funds }}{\text { Required amount of stable funds }}$ 
To ensure their liquidity, Basel III expects banks to keep this ratio above $100 \%$. The available amount of stable funds is defined as the total amount of bank capital, liabilities with a maturity equal or greater than one year, and the share of stable demand deposits and time deposits with maturity of less than one year that would be expected to stay within the bank. The required amount of stable funding is the amount of assets that could not be monetized easily or used as collateral for secured borrowing during a liquidity stress period.

Because calculating NSFR based on BIS (2010) is difficult due to the unavailability of a detailed breakdown of the balance sheet, we approximate it with Bankscope data using the weights defined in Vazquez and Federico (2015). The detailed components and their weights are presented in Table 3. The departures from the Basel III weights are detailed in Vazquez and Federico $(2015)^{2}$.

[Insert Table 3]

\subsubsection{Interbank network}

In this research, we aim to investigate the relationship between network topology of the interbank market and the NSFR ratio. To achieve this, we construct our banking network variables based on the lending-borrowing relationships in the interbank loan and deposit markets. A substantial drawback when studying the interbank loan-deposit market is the difficulty to access bilateral exposure data for individual banks as they are not required to report them to regulatory authorities in most of the European countries. Balance sheets only provide us with information on the individual bank's aggregate loans and deposits to and from all other banks. Therefore, to scrutinize the network characteristics at the bank level, we have to predict these bilateral relationships by applying mathematical algorithms.

There are several studies such as Anand et al. (2015); Elsinger et al. (2006) and Upper \& Worms (2004) that introduce and extend the ways to predict missing values and filling in the blank. The commonly used techniques are maximum entropy (ME) and minimum density (MD)

\footnotetext{
${ }^{2}$ For example, as it is not possible to split loans according to their type or maturity, a weight of $100 \%$ is assigned to total loans. As other earning assets are supposed to be more liquid, an average weight of $35 \%$ is assigned.
} 
algorithms. However, maximum entropy is not an appropriate estimation method for this study due to its assumption that each bank diversifies its loan-deposit portfolio as evenly as possible within all other banks in the network and tends to create a complete network that is too far from reality. ME could be a suitable method for predicting a network if there was no information on the banks' state of interconnectedness. However, the literature has outlined some steady features of interbank networks. We do have some knowledge about their sparsity (Cocco et al. 2009), the tendency of smaller banks to interact with limited money center banks (Craig \& von Peter, 2014) and eventually the fact that interacting with all possible banks is too costly based on information refinement and operational risk (Anand et al., 2015). Anand et al. (2015) highlight the hierarchical attributes of the interbank loan-deposit market which show that most of the banks are interested in interacting with a limited number of banks whose preferences conveniently match with each other. Thus, hereupon we use the minimum density algorithm introduced by Anand et al. (2015) to build our network. A notable point of applying this method is its economic rationality: producing and maintaining extra interbank links is costly and should be minimized. A detailed description of the minimum density algorithm is provided in the appendix.

\subsubsection{Network variables definitions}

To study banking network topology, we first need to characterize its features by defining each bank as a node which is indexed by $\mathrm{i}=1$ to $\mathrm{N}$ and the link that connects node $\mathrm{i}$ to $\mathrm{j}$ by $\mathrm{c}_{\mathrm{ij}}$. The interbank market is a directed network in nature by the fact that if node $i$ has a link with node $\mathrm{j}$, it is not necessary that node $\mathrm{j}$ be linked with $\mathrm{i}$, in other words $\mathrm{c}_{\mathrm{ij}} \neq \mathrm{c}_{\mathrm{ji}}$. Another important feature is the path length of node $i$ to $j$ which denotes the number of links from $i$ to $j$ and shows that not all the nodes connect to each other directly, and there is the possibility of an indirect link between two different nodes through others. The shortest possible distance between two given nodes, $\mathrm{i}$ and $\mathrm{j}$, is called geodesic path and is denoted by $\mathrm{g}_{\mathrm{ij}}$. Sometimes there is more than one geodesic path between a pair of nodes.

The network tools for capturing connectedness between nodes that are applied in this study are based on degree and centrality measurements, which are described below.

We divide the network measurements in two categories: 
1) Local network statistics comprise In-Degree, Out-Degree, Degree and Clustering Coefficient that quantify each bank's interconnectedness with its local neighbors.

2) System-wide network statistics assess the interbank network interconnectedness based on each bank's position in the whole network. They correspond to variables named Authority, Hub, Betweenness Centrality, Closeness centrality and PageRank.

In-degree, in network science, has been defined as the number of incoming links to each node. In our study, it corresponds to the number of deposits held by bank i coming from all other banks in the network.

$D_{j}^{i n}=\sum_{j} a_{j i}$

Out-degree is the number of outgoing links from each node, which corresponds, to the number of loans originated from bank i to other banks.

$D_{j}^{\text {out }}=\sum_{j} a_{i j}$

Degree is the sum of the node's in-degree and out-degree.

$D_{i}=D_{j}^{\text {in }}+D_{j}^{\text {out }}$

Clustering coefficient (CC) illustrates the probability of interconnectedness of each pair counterparties of node $i$ which are connected to each other as well. In other words, if we consider bank $\mathrm{i}$, it measures the probability of a connection between bank $\mathrm{j}$ and $\mathrm{k}$ if both connected to bank i. To describe the clustering coefficient, consider a binary network defined by graph $\mathrm{G}=$ $(A, N)$, in which $\mathrm{N}$ is the number of banks and $\mathrm{A}$ is its adjacency matrix that contains $\mathrm{a}_{\mathrm{ij}}$. $\mathrm{a}_{\mathrm{ij}}=1$ if there is a direct link between bank $i$ and $j$ and equal to zero otherwise. Assume $D_{i}$ is the degree of bank $\mathrm{i}$ which is defined as the number of its neighbors, so the percentage of i's pair neighbors that are themselves neighbors is measured based on the ratio of bank i triangles to all possible triangles produced by graph $\mathrm{G}$ and form the clustering coefficient measure.

$C C_{i}(A)=\frac{\frac{1}{2} \sum_{j \neq i} \sum_{h \neq(i, j)} a_{i j} a_{i h} a_{j h}}{\frac{1}{2} D_{\mathrm{i}}\left(D_{\mathrm{i}}-1\right)}$ 
Hub centrality measures how important each bank is according to its total number of interbank borrowers (out-degree), compared to other banks in the network.

Authority centrality points the importance of each bank's total number of interbank lenders (In-Degree) relatively to the other banks in the network.

Hub and Authority are calculated based on the HITS algorithm (Kleinberg, 1999).

Two other important statistics (Betweenness and Closeness centrality) capture noteworthiness of banks' positions in the network and show which banks are more central than others are.

Betweenness centrality depicts the ratio of links between bank $\mathrm{j}$ and bank $\mathrm{k}$ that passed through bank $\mathrm{i}$ compared to the total number of links between bank $\mathrm{j}$ and bank $\mathrm{k}$. Likewise increasing bank i's betweenness ratio shows an increasing intermediary role of bank i in the network, because every relationship between $\mathrm{j}$ and $\mathrm{k}$ should pass through $\mathrm{i}$, so $\mathrm{i}$ has the power to strengthen or dampen a relationship based on its intrinsic situation. Banks characterized by a higher betweenness ratio are considered as dominant intermediary banks in the system:

$B_{i}=\sum_{j<k} \frac{g_{j i k}}{g_{j k}}$

In which $g_{j i k}$ is the number of geodesic path between bank $\mathrm{i}$ and $\mathrm{k}$ which pass through bank $\mathrm{i}$.

Closeness centrality measures how close each bank is to the other banks in the network based on distance ${ }^{3}$. Closeness captures to what extent bank i could send a signal to other banks more directly and with less distance. So banks with a high closeness ratio could be expected to have stronger access to interbank funding as they can lend or borrow more directly to and from other banks than the rest. It is calculated by measuring the reverse distance of each bank to all other banks:

$C_{i}=\frac{1}{\sum_{j} \sum_{j=1}^{g} d_{i j}}$

In which $d_{i j}$ is the shortest distance between banks $\mathrm{i}$ and $\mathrm{j}$.

\footnotetext{
3 Distance is measured based on the number of intermediate banks between two arbitrary banks.
} 
PageRank centrality is a centrality measurement based on Google's algorithm proposed in Page et al. (1998). This variable considers WWW (World Wide Web) as a digraph. Its specific feature that makes it a unique and significant network parameter is its capability of considering to what extent the importance of neighbors could determine the importance of each bank. It is defined as:

$P R(i)=\frac{(1-d)}{N}+d \sum_{j \in N-(i)} \frac{P R(j)}{L(j)}$

Where $\mathrm{i}$ is the set of banks, $\mathrm{L}$ is the number of linkages which depart from its outer degree and $\mathrm{d}$ is a factor that Winograd (1999) recommend setting at 0.85 .

All these network variables are calculated based on the software developed by Bastian and Heymann (2009).

\subsubsection{Control variables}

We also include a set of control variables known to affect the liquidity of banks (Chen et al., 2015; Deyoung \& Jang, 2016; Dietrich et al. 2014; Distinguin et al., 2013; Hong et al. 2014; King, 2013; Mattana \& Panetti, 2014; Roman \& Şargu, 2014).

We first control for bank size by introducing the natural logarithm of total assets (LogTA) in our regressions. Larger banks are indeed expected to have easier access to liquidity on the interbank market than small banks but can also benefit from their stronger support from the lender of last resort for safety net considerations.

We also introduce the Z-Score, which is an indicator of bank distance to bankruptcy. The higher this ratio is, the lower the probability of default. Z-score in this study is calculated as:

Zscore $=\frac{\text { RoAmma }+\left(\frac{\text { Equity }}{T A}\right) m m a 3}{\text { ROAsdma } 3}$

where ROAmma3 is the 3-year rolling window average return on assets defined as the ratio of net income to average total assets, (Equity/TA)mma3 represents the 3-year rolling window average of equity to total assets and ROAsdma3 stands for the 3-year rolling window standard deviation of the return on assets. All the ratios are in percentages. The expected relationship 
between Z-score and liquidity is negative. By reducing their default probability, banks are more willing to increase their revenue by funding their assets with less stable liabilities (Horvath et al. (2016)).

We also include the Return on assets (ROA) and the net interest margin (NIM). The expected signs for the coefficients of these variables are ambiguous. ROA measures the bank's overall profitability and could be either positively (Chen et al., 2015; Dietrich et al., 2014 and Roman \& Şargu, 2014) or negatively (Bonfim \& Kim, 2012) associated with bank liquidity. On the one hand, banks with higher overall profitability tend to adopt riskier liquidity management strategies to boost their income. On the other hand, banks that are more profitable hold more liquidity possibly to reduce the likelihood of fire sale of illiquid assets. NIM measures the portion of a bank's profitability obtained with its traditional intermediation function. Similarly to ROA, we expect either a positive (Bonfim \& Kim, 2012) or a negative coefficient (Hong et al., 2014) for NIM. We consider the cost to income ratio (Cost-income) as proxy of bank cost efficiency. We expect a negative coefficient for Cost-income as banks with higher cost efficiency (lower value of Cost-income) on average store more liquidity (Bonfim \& Kim, 2012). We also consider the ratio of equity to total assets (Eq_TA) as a proxy of bank leverage. However, to avoid bias in our estimations due to potential endogeneity issues, we used the one year lagged of this variable. We expect a positive impact of Eq_TA on bank liquidity as lower bank leverage reduce its liquidity risk (Cucinelli, 2013).

Our country level control variables comprise the Central bank policy rate (CB policy rate), the Natural logarithm of GDP per capita, Inflation, banking sector size and HHI index which is calculated based on banks' total assets. The CB policy rate is a proxy of monetary policy. When the central bank's policy rate is relatively low, credit supply increases (Berger, 2011; Bernanke \& Blinder, 1992), which negatively affects bank liquidity . In line with Distinguin et al. (2013), we expect a positive relationship between CB policy rate and bank liquidity.

GDP per Capita is a country's gross domestic product per capita. An increase in GDP per Capita induces higher investment opportunities that lead banks to lend more and store less liquidity. Distinguin et al. (2013) find that economic growth positively impacts bank illiquidity. We expect a negative relationship between GDP per capita and bank liquidity. Inflation is 
another control variable that is used in this study. Higher inflation lessens money value and raises a bank's opportunity cost of storing liquidity (Chiu \& Meh, 2008). Hence, we expect that inflation will negatively affect a bank's liquidity. We also use the ratio of banking sector size to GDP to account for differences in financial development across the countries in our sample. We expect a positive relationship between banking sector size and bank liquidity. Higher financial development reduces a bank's investment opportunity due to higher bank competition and leads to higher bank liquidity. To control for market concentration, we include the HerfindahlHirschman index (HHI). HHI is calculated as the sum of the squared market shares (based on total assets) of all banks in each country. Market concentration could affect credit availability. When market concentration is higher, banks have more freedom to diversify their loan portfolio, offer flexible interest rates and attract more funds (Petersen \& Rajan, 1995). They are thereby expected to store less liquidity. We hence expect a negative relationship between HHI and bank liquidity.

Given that European banks have experienced both the global financial crisis of 20072008 and the European sovereign debt crisis of 2010-2011, we construct two dummy variables to capture the effects of both crises. Each dummy variable takes the value of one in the aforementioned crisis years and zero otherwise. Bank specialization dummy variables comprising an Investment bank dummy and a Real-estate bank dummy are also introduced in the regressions.

\subsection{Methodology}

In this paper, we question whether interbank network topology impacts bank liquidity ratios and specially NSFR. Specifically, we use individual bank network indicators based on their loans to other banks and deposits from other banks and test how they affect NSFR and also other liquidity ratios for robustness. Because, such network variables are likely to be determined by specific factors (such as the size and shape of the industry in each country and at each point in time and the type interaction with the central bank, or other environmental or individual bank factors...) to address possible endogeneity issues, we conduct instrumental variable (IV) estimations: 


$$
\begin{aligned}
\operatorname{NSFR}_{i, t}=\alpha_{0} & +\alpha_{1} \operatorname{Netw}(x)_{i, t}+\alpha_{2} B_{i, t}+\alpha_{3} \text { Eq_TA }_{i, t-1}+\alpha_{4} C_{j, t}+\alpha_{5} \text { Crisis_Subprime }_{t} \\
& +\alpha_{6} \text { Crisis_Sovereign }_{t}+\alpha_{7} \text { Investment }_{i}+\alpha_{8} \text { Realestate }_{i}+\mu_{\mathrm{i}, \mathrm{t}}+\varepsilon_{i, t}
\end{aligned}
$$

where $\alpha_{0}$ is a constant, $\operatorname{Netw}(x)$ is a network variable that is either In-degree, Out-degree, Betweenness centrality, Closeness Centrality, Hub, Authority, PageRank or Clustering Coefficient ${ }^{4}$. Except for Betweenness centrality and Closeness Centrality ${ }^{5}$, to deal with possible endogeneity of the network variables, we instrument them with their first, second, and third lagged values. $B_{i, t}$ is a vector of bank level control variables including Bank size, Z-score, Net interest margin, Return on assets and Cost-income ratio. $E q_{-} T A_{i, t-1}$ is the one year lagged value of Equity to total assets ratio. $C_{j, t}$ is a vector of country level control variables that comprises the Central bank policy rate, the Natural logarithm of GDP per capita, Inflation, banking sector size to GDP ratio and HHI index which is calculated based on banks total

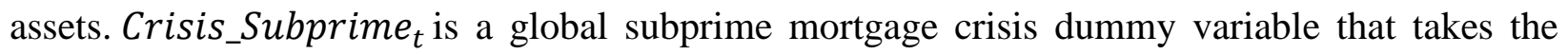
value of one for the 2007-2008 period.Crisis_Sovereign $n_{t}$ is an European sovereign crisis dummy variable that takes the value of one for the period of 20102011. Investment ${ }_{i}$ and Realestate Re $_{i}$ are the bank specialization dummy variables for Investment and Real estate banks. $\mu_{i, t}$ is bank fixed effects and $\varepsilon_{i, t}$ is error term.

\section{Results}

We first investigate the link between interbank network connectedness and the bank's NSFR ratio and then look at how various factors such as the crisis and the size of the banking sector could affect such a relationship.

\footnotetext{
${ }^{4}$ Table A2 in appendix presents a correlation matrix of the independent variables used in this study. As the network variables are highly correlated, we introduce them in the equation one by one.

${ }^{5}$ In the case of Betweenness centrality and Closeness Centrality, we introduce as instruments the first year lagged value of PageRank in addition to the first and second lagged value of our network variable in order to pass the Hansen overidentification test. Since PageRank depicts the central position of each bank according to the importance of its counterparties, the interconnectedness status of those counterparties could also determine the strategic position of the bank in the network, which is measured by Betweenness and Closeness Centrality.
} 


\subsection{Impact of network topology on bank liquidity ratio}

The instrumental variable (IV) panel regression results are presented in table 4. The validity of our instruments were checked using the Hansen test and the Kleibergen-Paap LM test.

[Insert Table 4]

As shown in Table 4, concerning the local network statistics, by increasing the number of direct lenders (In-Degree), banks are less likely to store more stable funds because they believe they could have access to interbank funds easily in case of a liquidity shortage. However, the relationship is reversed in the case of increasing direct borrowers (Out-Degree) as banks appear to be more conservative regarding the level of liquid assets they hold, possibly because they are more exposed to default because of a larger number of borrowers. Our results show that building and raising clusters of triangular relationships between banks leads to an increase in the NSFR ratio. Banks that lend to two other banks that are themselves connected (Clustering Coefficient) are more cautious about the level of liquidity they store. In fact, the default of each borrower bank $(\mathrm{B}, \mathrm{C})$ has a direct and indirect consequence on the bank located in the vertices of a triangular relationship (A). The direct effect is when bank B defaults to pay Bank A, and the indirect effect is when it defaults in paying $\mathrm{C}$ at the same time which leads to the default of $\mathrm{C}$ as well, and produces synergy effects. Thus, in this case, because of higher uncertainty, banks appear to be more cautious and tend to store more liquidity.

Concerning system-wide network measurements, our findings highlight that banks which play a major role in the interbank network, either as dominant direct lenders $(\mathrm{Hub})$ or borrowers (Authority), exhibit a lower NSFR ratio. Hence, banks that hold a significant position in the network as direct network lenders or borrowers are more confident and store less liquidity because they have direct access to vast interbank funds. A stronger intermediation role in the whole network, which is measured by Betweenness Centrality, also has a negative influence on the NSFR ratio indicating that such banks would less rely on liquid assets to cover unexpected liquidity shocks as well as stable funds and would have higher tendency to rely on interbank debt possibly because bailout expectations could be higher for such interconnected intermediaries. Similarly, higher accessibility to the rest of the network by decreasing the number of intermediating banks between each pair entities (Closeness Centrality) leads banks to store less liquidity. Finally, banks that are connected to central positioned banks (banks that are critical 
hubs or intermediaries within the market) in the interbank network (PageRank) also exhibit a lower NSFR ratio possibly because of strong links with highly connected counterparties.

Concerning the bank-level liquidity determinants, bank size has a negative and significant effect on NSFR which is in line with Chen et al. (2015) and Hong et al. (2014). Large banks have more options to access liquidity through other channels than small banks. They thereby set a lower NSFR to decrease the cost of holding a larger amount of liquid assets.Net interest margin is highly significant with a negative coefficient. A higher net interest margin, which is in general obtained by holding longer illiquid assets, pushes banks to be less prudent than otherwise. ROA has a positive and significant impact on NSFR in line with the results of Chen et al. (2015); Dietrich et al. (2014) and Roman \& Şargu (2014). Banks that are more profitable hold more liquid assets possibly to prevent them from fire sales of illiquid assets. The positive coefficient of the equity to total assets ratio is in accordance with the studies of Chen et al. (2015); Cucinelli (2013); Dietrich et al. (2014); Hong et al. (2014) and Vodová (2011) but opposite to the findings of Roman \& Şargu (2014) illustrating that well capitalized banks set a higher NSFR ratio. The negative impact of the Z-score in our model indicates that banks with a lower default probability tend to store less liquidity. The negative coefficient of the Cost-income ratio is in line with Bonfim \& Kim (2012) indicating that less cost efficient banks hold less liquidity. Such banks can increase their profits by investing more in illiquid assets, which in turn earn a higher rate of return.

Concerning country-level liquidity determinants, the banking sector size to GDP ratio has a positive influence on the NSFR ratio and shows that banks in a country with a larger banking sector set a higher NSFR ratio. The negative relationship between the HHI index and NSFR suggests that higher banking concentration forces banks to invest less in liquid and stable assets, which leads to a lower NSFR ratio. Our results also show a negative and positive relationship between inflation and investment specialization with the NSFR ratio respectively.

In addition, our baseline results point out that both the sovereign and subprime crises have a negative and statistically significant effect on the NSFR ratios of European banks. 


\subsection{Effect of interbank network topology on bank liquidity ratio during crises}

We consider the effect of network topology on structural liquidity of banks within crisis periods by looking at both the global financial crisis of 2007-2008 and the European sovereign debt crisis of 2010-2011. Both crises are meaningfully important for interconnectedness of banks in the euro area interbank market as during these events banks were reluctant to deal with each other on unsecure interbank markets and preferred to interact through the Eurosystem. Under such circumstances, the role played by networks is expected to dramatically change. In addition, during crisis periods, banks are more likely to be hoarding liquidity and cut their lending leading to frozen liquidity markets.

To determine whether the network characteristics have a different impact on liquidity during crises, we interact the network variables with the crisis dummies.

[Insert Table 5]

[Insert Table 6]

Table 5 and Table 6 present the results of the estimation augmented with interaction terms ${ }^{6}$.

Our results indicate that Local network indicators, In-Degree, Out-Degree and Clustering Coefficient, are statistically significant during normal times, which is consistent with our general results. However, Clustering Coefficient loses its significance and Out-Degree has a weaker impact during crisis times. The only exception is the number of direct lenders (In-Degree) that has a stronger negative impact on NSFR during crisis times. Our results also show that although there still is a negative relationship between Closeness centrality and the NSFR ratio during crisis times, its negative impact is weaker.

In general, our findings show that during crisis times, banks set their liquidity ratio based on their position throughout the network and less on their local position on the interbank market. This is possibly because of higher contagion risk and because banks become more sensitive to their system-wide connections.

\footnotetext{
${ }^{6}$ In all the tables, we only report the results obtained for the variables of interest. Detailed results are available upon request.
} 


\subsection{Effect of interbank network topology on liquidity ratio in large and small banking sectors}

Countries with a relatively larger banking sector compared to the economy are more exposed to contagion risk compared to other countries, probably because financial system impairments, either global or partial, would result in severe negative outcomes for the economy (BIS and IMF, 2009).

Especially in the case of the European Union, monitoring individual banks' liquidity management is a critical issue for regulators because of the spillover effects from one Euro country to the other. Also, banks operating in relatively larger or smaller banking sectors might show a different behavior in terms of liquidity ratio targets because of higher or lower contagion risk in differently scaled networks. To examine the impact of interbank network topology on banks' liquidity ratios in countries with distinct features, we introduce a dummy variable that captures the importance of the banking sector in each European country by dividing the sum of banks' total assets of each country to GDP annually. The countries with a relative banking sector size higher than the median value in each year are classified as large and the rest as small networks. To determine whether the network characteristics have a different impact on liquidity for large versus small networks, we interact the network variables with the banking sector relative size dummy. The size dummy takes the value of one for large banking sectors (above the median) and zero otherwise.

\section{[Insert Table 7]}

Table 7 presents the results. Our findings show that local measures of interbank network including Out-Degree and Clustering coefficient are only significant and positively related to the NSFR ratio in small network countries. Banks operating in countries with larger banking sectors do not set their liquidity ratio based on these local positions in the interbank market.

Hub, Authority and PageRank are significant and have a negative impact on NSFR in both large and small networks, although the negative impact in large banking sectors is weaker than in small ones. One possible explanation is that the degree of financial system fragility is higher in a large network because of larger bank balance sheets that could lead to more severe consequences during liquidity shocks. 


\section{Robustness Checks and Further Issues}

To check the robustness of our results and to go deeper in our empirical investigation, we conduct several sensitivity analyses.

\subsection{Network constructed with all types of banks}

As pointed out above, we have conducted our estimations by excluding savings, cooperative and mutual banks from our sample to construct our banking exposure network more accurately, as those banks tend to interact with the counterparties from the same group and are less likely to engage in lending-borrowing relationships with banks beyond their specialization. However, to check the robustness of our results we reconstruct our exposure network with the assumption that banks of all type tend toward building interbank relationships with each other regardless of their specialization. Hence, we add savings, cooperative and mutual banks to our sample, run the MD algorithm based on this extended sample and estimate network topology parameters accordingly.

\section{[Insert Table 8]}

Table 8 summarizes the regression results. Except Out-Degree, Betweenness Centrality and Clustering Coefficient that are not statistically significant, our results remain the same. The heterogenous interbank network structure of cooperative and savings bank compared to those of other types of banks could explain the deviation from our baseline results for these three network variables.

\subsection{Alternative measures of bank Liquidity}

We also estimate our IV model based on three alternative definitions of the liquidity ratio that are represented by the ratio of net loans to total assets (NL_TA), the ratio of net loans to deposits and short-term funds (NL_DSTF) and the ratio of liquid assets to deposits and shortterm funds (LA_DSTF). NL_DSTF considers the amounts of deposits and short-term debt employed by banks to fund their loan portfolio. A lower ratio indicates higher bank liquidity (higher preference to fund loans with shorter-term debt and customer deposits and consequently 
less stable funds). NL_TA measures the main portion of a bank's illiquid assets (Loans) compared to total assets. A lower value of this ratio indicates higher bank liquidity. Finally, LA_DSTF depicts the amount of liquid assets which are locked into deposits and short-term funds and that can be used during sudden withdrawals. A higher ratio shows higher bank liquidity. Table 9 summarizes the regression results. Concerning LA_DSTF, only Out-Degree is significant and its positive coefficient is consistent with the results obtained with the NSFR model. Nevertheless, we obtain different results when we use NL_DSTF and NL_TA. In the light of these two indicators, higher local or system-wide access to the interbank market leads banks to be more cautious in terms of maturity transformation.

[Insert Table 9]

\subsection{Highly liquid banks}

Up to here we find that banks with strong (weak) access to the interbank market set lower (higher) liquidity ratios presumably to decrease the cost of keeping liquid assets in their balance sheets. The preferences of highly liquid banks toward lending and storing liquidity are not similar to those of less liquid banks. Freixas et al. (2011) highlight that liquid banks have an inelastic supply of interbank funds, and illiquid banks have an inelastic demand for those funds. Therefore, they trade on the interbank market based on their profit maximization objective. Following the full implementation of Basel III, such demand and supply inelasticity could change as Basel III would require all banks to be highly liquid. To predict the impacts of these changes, we run our regression on subsamples of highly versus less liquid banks. Table A3 presents descriptive statistics for such banks. To isolate highly liquid banks, we construct four subsamples: i) Banks with NSFR greater than or equal to one (Basel III minimum regulatory requirement), Banks with NL_TA less than or equal to the $25^{\text {th }}$ percentile, iii) banks with NL_DSTF less than or equal to the $25^{\text {th }}$ percentile and iv) banks with LA_DSTF greater than or equal to the $75^{\text {th }}$ percentile.

\section{[Insert Table 10]}

Our results (Table 10) indicate that, on the whole, network topology is not significant in explaining liquidity ratios for highly liquid banks. An exception is that local or system-wide 
measures are significant factors to explain LA_DSTF. A more important role in the network makes such highly liquid banks store more liquidity relatively to their short-term liabilities in their balance sheets.

\section{[Insert Table 11]}

Table 11 summarizes the regression results for highly liquid banks where NSFR is the dependent variable during crisis times and normal times. Again, network variables are not significant for highly liquid banks during distress times. Hence, our results suggest that during crisis times for banks that are highly liquid (NSFR >1) strong access to interbank funds because of better interconnectivity or weaker access does not lead to a different behavior in terms of liquidity ratio setting.

Table A4 presents distribution of highly liquid European banks in our sample during crisis times and overall. The results highlight a higher percentage of highly liquid banks in small banking sectors (e.g. Czech Republic and Malta) versus lower percentage in large banking sector countries (e.g. France and Spain).

\subsection{Systemically Important Banks}

With Basel III, very large banks, which are viewed as systemically important financial institutions (SIFIs) are considered to be a major concern for regulators. To go deeper and look into the behavior of such institutions, we focus on the subsample of SIFIs in line with the 2015 update of the G-SIB list that is published by $\mathrm{FSB}^{7}$. Table A5 presents descriptive statistics for such banks including their net lending position, which shows that on average such banks are net borrowers over our sample period.

On the whole, our findings (see table 12) indicate that SIFIs do not consider their network topology to set their NSFR ratio in normal times. However, during crisis times, they consider their system-wide network position and adopt a more cautious behavior when they have a greater intermediary role in the network.

\footnotetext{
${ }^{7}$ Table A6 in Appendix presents the 2015 list of G-SIBs that is published by FSB.
} 
To predict the effects of the implementation of Basel III on the SIFIs' liquidity management based on their network topology, we run regressions on subsamples of highly liquid $(\mathrm{NSFR} \geq 1)$ and less liquid (NSFR $<1)$ SIFIs (Table 12, columns $2 \& 3$ ). Surprisingly, our results show that network topology has almost contradictory effects on highly liquid and less liquid SIFIs. While strong system-wide access to interbank funds weakens the NSFR of less liquid SIFIs, it strengthens the NSFR of highly liquid ones. Eventually, strong local access to interbank funds documented by the total numbers of direct lenders lead highly liquid SIFIs to set higher NSFR.

\subsection{Fixed effect model and additional explanatory power of network variables}

In addition, we perform a robustness check by estimating a panel data fixed effect model. As illustrated in Table 13, the results are close to those of the instrumental variables model for the network variables In-Degree, Hub, Authority and PageRank.

[Insert Table 13]

Furthermore, to determine the additional explanatory power of our network topology statistics to liquidity models previously considered in the literature we perform a Wald test. The results indicate that In-Degree, Hub, Authority and PageRank significantly add value to explain liquidity ratios.

\section{Conclusion}

Bank liquidity models have neglected the role played by interbank network characteristics and have essentially focused on the amount of liquidity that banks store in their balance sheet. In this paper, we augment traditional liquidity models with network statistics to assess their explanatory power and investigate how banks set their liquidity ratio depending on their network characteristics in the interbank market. Using an instrumental variables approach applied to a dataset of banks from 28 European countries, our study shows that liquidity ratios are not only dependent on the macro environment and the individual bank characteristics outlined in the literature but also on their position in interbank networks. More powerful strategic positions in the interbank network, higher direct dominant lending and borrowing positions and 
eventually higher importance of counterparties lead banks to set lower liquidity ratios as they have easier access to short term interbank funding. However, during crisis times banks set their liquidity ratio on the basis of their system-wide position in the interbank network and less on their local position on the interbank market revealing the fragility of networks during distress periods. Moreover, banks' local position in the interbank network does not affect their liquidity ratios in countries with larger network sizes presumably because of the higher associated contagion risk during turmoil. Our results highlight that strongly connected banks in the interbank market might be underestimating liquidity risk possibly because of their tooconnected-to-fail position. Our findings cast doubt on the Basel III uniform liquidity requirements to banks with different connectedness characteristics and support the need to implement minimum liquidity requirements by taking into account the interbank network characteristics of each banking industry and possibly of each systemically important bank.

\section{References:}

Allen, W., \& Moessner, R. (2012). The liquidity consequences of the euro area Sovereign Debt crisis. BIS Working Papers, 14(390), 103-125. Retrieved from

Anand, K., Craig, B., \& von Peter, G. (2015). Filling in the blanks: network structure and interbank contagion. Quantitative Finance, 15(4), 625-636.

Basel Committee on Banking Supervison. (2010). Basel III: International framework for liquidity risk measurement, standards and monitoring, December 2010. Supervision.

Berger, A. N. (2011). Bank Liquidity Creation, Monetary Policy, and Financial Crises Bank Liquidity Creation, Monetary Policy, and Financial Crises.

Bernanke, B. S., \& Blinder, A. S. (1992). The Federal Funds Rate and the Channels of Monetary Transmission. American Economic Review, 82(4), 901-921.

Blundell, R., \& Bond, S. (1998). Initial conditions and moment restrictions in dynamic panel data models. Journal of Econometrics, 87(1), 115-143.

Bonfim, D., \& Kim, M. (2012). Liquidity Risk in Banking: Is there herding? Banco de Portugal Working Paper, 2012(12), 40.

Caccioli, F., Farmer, J. D., Foti, N., \& Rockmore, D. (2015). Overlapping portfolios, contagion, and financial stability. Journal of Economic Dynamics and Control, 51, 50-63.

Caccioli, F., Shrestha, M., Moore, C., \& Farmer, J. D. (2014). Stability analysis of financial contagion due to overlapping portfolios. Journal of Banking and Finance, 46(1), 233-245.

Capponi, A., \& Chen, P.-C. (2015). Systemic risk mitigation in financial networks. Journal of Economic 
Dynamics and Control, 58, 152-166.

Changqing, L., Chi, X., Cong, Y., \& Yan, X. (2015). Measuring financial market risk contagion using dynamic MRS-Copula models: The case of Chinese and other international stock markets. Economic Modelling, 51, 657-671.

Chen, T.-H., Chou, H.-H., Chang, Y., \& Fang, H. (2015). The effect of excess lending on bank liquidity : Evidence from China. International Review of Economics \& Finance, 36, 54-68.

Chiaramonte, L., \& Casu, B. (2015). Capital and Liquidity Ratios and Financial Distress. Evidence from the European Banking Industry Laura Chiaramonte* and Barbara Casu \# This version: 20 December 2015. The British Accounting Review, (December).

Chinazzi, M., Fagiolo, G., Reyes, J. A., \& Schiavo, S. (2013). Post-mortem examination of the international financial network. Journal of Economic Dynamics and Control, 37(8), 1692-1713.

Chiu, J., \& Meh, C. (2008). Financial Intermediation, Liquidity and Inflation. Working Paper.

Cocco, J. F., Gomes, F. J., \& Martins, N. C. (2009). Lending relationships in the interbank market. Journal of Financial Intermediation, 18(1), 24-48.

Craig, B. R., Fecht, F., \& Tümer-Alkan, G. (2015). The role of interbank relationships and liquidity needs. Journal of Banking and Finance, 53, 99-111.

Craig, B., \& Von Peter, G. (2014). Interbank tiering and money center banks. Journal of Financial Intermediation, 23(3), 322-347.

Craig, B., \& von Peter, G. (2014). Interbank tiering and money center banks. Journal of Financial Intermediation, 23(3), 322-347.

Cucinelli, D. (2013). The determinants of bank liquidity risk within the Context of Euro Area. Interdisciplinary Journal of Research in Business, 2(10), 51-64.

Deyoung, R. (2015). Do Banks Actively Manage their Liquidity ? JOURNAL OF BANKING FINANCE, (November).

Deyoung, R., \& Jang, K. Y. (2016). Do banks actively manage their liquidity ? JOURNAL OF BANKING FINANCE, 66, 143-161.

Diamond, D. W., \& Dybvig, P. H. (n.d.). Bank Runs , Deposit Insurance, and Liquidity, 91(3), 401-419.

Dietrich, A., Hess, K., \& Wanzenried, G. (2014). The good and bad news about the new liquidity rules of Basel III in Western European countries. Journal of Banking and Finance, 44(1), 13-25.

Distinguin, I., Roulet, C., \& Tarazi, A. (2013). Bank regulatory capital and liquidity: Evidence from US and European publicly traded banks. Journal of Banking and Finance, 37(9), 3295-3317.

Dungey, M., \& Gajurel, D. (2015). Contagion and banking crisis - International evidence for 2007-2009. Journal of Banking and Finance, 60, 271-283.

Elsinger, H., Lehar, A., \& Summer, M. (2006). Risk Assessment for Banking Systems. Management Science, September(May 2016), 1301-1314.

Freixas, X., Martin, A., \& Skeie, D. (2011). Bank liquidity, interbank markets, and monetary policy. Review of Financial Studies, 24(8), 2656-2692. 
Fry-McKibbin, R., Martin, V. L., \& Tang, C. (2014). Financial contagion and asset pricing. Journal of Banking \& Finance, 47, 296-308.

Glasserman, P., \& Young, H. P. (2015). How likely is contagion in financial networks? Journal of Banking and Finance, 50, 383-399.

Gobat, J., Yanase, M., \& Maloney, J. (2014). The Net Stable Funding Ratio: Impact and Issues for Consideration. IMF Working Paper.

González-Avella, J. C., Quadros, V. H., \& Iglesias, J. R. (2016). Network topology and interbank credit risk. Chaos, Solitons and Fractals, forthcomin, 1-9.

Hong, H., Huang, J.-Z., \& Wu, D. (2014). The information content of Basel III liquidity risk measures. Journal of Financial Stability, 15, 91-111.

Horvath, R., Seidler, J., \& Weill, L. (2016). How bank competition influences liquidity creation. Economic Modelling, 52, 155-161.

Huang, W.-Q., Zhuang, X.-T., Yao, S., \& Uryasev, S. (2016). A financial network perspective of financial institutions' systemic risk contributions. Physica A: Statistical Mechanics and Its Applications, 456, 183-196.

in 't Veld, D., \& van Lelyveld, I. (2014). Finding the core: Network structure in interbank markets. Journal of Banking and Finance, 49, 27-40.

Iori, G., G., D. M., Precup, O. V., Gabbi, G., \& Caldarelli, G. (2008). A network analysis of the Italian overnight money market. Journal of Economic Dynamics and Control, 32(1), 259-278.

King, M. R. (2013). The Basel III Net Stable Funding Ratio and bank net interest margins. Journal of Banking and Finance, 37(11), 4144-4156.

Kleinberg, J. M. (1999). Authoritative Sources in a Hyperlinked Environment. Journal of the ACM, 46(May 1997), 668-677.

Kontogeorgis, G. M. (2016). Financial networks, bank efficiency and risk-taking. Journal of Financial Stability.

Kuzubaş, T. U., Ömercikoğlu, I., \& Saltoğlu, B. (2014). Network centrality measures and systemic risk: An application to the Turkish financial crisis. Physica A: Statistical Mechanics and Its Applications, 405, 203-215.

Langfield, S., Liu, Z., \& Ota, T. (2014). Mapping the UK interbank system. Journal of Banking and Finance, 45(1), 288-303.

Lenzu, S., \& Tedeschi, G. (2012). Systemic risk on different interbank network topologies. Physica A: Statistical Mechanics and Its Applications, 391(18), 4331-4341.

León, C., \& Berndsen, R. J. (2014). Rethinking financial stability: Challenges arising from financial networks' modular scale-free architecture. Journal of Financial Stability, 15, 241-256.

Li, S., He, J., \& Zhuang, Y. (2010). A network model of the interbank market. Physica A: Statistical Mechanics and Its Applications, 389(24), 5587-5593.

Lux, T. (2015). Emergence of a core-periphery structure in a simple dynamic model of the interbank market. Journal of Economic Dynamics and Control, 52(September 2013), A11-A23. 
M. Bastian, S. Heymann, M. J. et al. (2009). Gephi: an open source software for exploring and manipulating networks. Proceedings of International AAAI Conference on Web and Social Media, 361-362.

Martinez-Jaramillo, S., Alexandrova-Kabadjova, B., Bravo-Benitez, B., \& Solórzano-Margain, J. P. (2014). An empirical study of the Mexican banking system's network and its implications for systemic risk. Journal of Economic Dynamics and Control, 40, 242-265.

Martinez-Jaramillo, S., Perez, O. P., Embriz, F. A., \& Dey, F. L. G. (2010). Systemic risk, financial contagion and financial fragility. Journal of Economic Dynamics and Control, 34(11), 2358-2374.

Mattana, E., \& Panetti, E. (2014). Bank liquidity, stock market participation, and economic growth. Journal of Banking \& Finance, 48, 292-306.

Page, L., Brin, S., Motwani, R., \& Winograd, T. (1998). 1 Introduction and Motivation 2 A Ranking for Every Page on the Web. World Wide Web Internet And Web Information Systems, 54(1999-66), 117.

Paltalidis, N., Gounopoulos, D., Kizys, R., \& Koutelidakis, Y. (2015). Transmission Channels of Systemic Risk and Contagion in the European Financial Network. Journal of Banking \& Finance, 61, 36-52.

Petersen, R., \& Rajan, M. A. (1995). The effect of credit market competition on lending relationships.

Roman, A., \& Şargu, A. C. (2014). Banks Liquidity Risk Analysis in the New European Union Member Countries: Evidence from Bulgaria and Romania. Procedia Economics and Finance, 15(14), 569-576.

Rørdam, K. B., \& Bech, M. L. (2009). The topology of Danish interbank money flows. Banks and Bank Systems, 4(4), 48-65.

Soramäki, K., Bech, M. L., Arnold, J., Glass, R. J., \& Beyeler, W. E. (2007). The topology of interbank payment flows. Physica A: Statistical Mechanics and Its Applications, 379(1), 317-333.

Souza, S. R. S. de, Silva, T. C., Tabak, B. M., \& Guerra, S. M. (2016). Evaluating systemic risk using bank default probabilities in financial networks. Journal of Economic Dynamics and Control, 66, 54-75.

Souza, S. R. S., Tabak, B. M., Silva, T. C., \& Guerra, S. M. (2015). Insolvency and contagion in the Brazilian interbank market. Physica A: Statistical Mechanics and Its Applications, 431(July 2011), 140-151.

Tonzer, L. (2015). Cross-border interbank networks, banking risk and contagion. Journal of Financial Stability, 18, 19-32.

Upper, C., \& Worms, A. (2004). Estimating bilateral exposures in the German interbank market: Is there a danger of contagion? European Economic Review, 48(4), 827-849.

Vazquez, F., \& Federico, P. (2015). Bank funding structures and risk: Evidence from the global financial crisis. Journal of Banking \& Finance, 61, 1-14.

Vitali, S., Battiston, S., \& Gallegati, M. (2016). Financial fragility and distress propagation in a network of regions. Journal of Economic Dynamics and Control, 62, 56-75.

Vodová, P. (2011). Liquidity of Czech commercial banks and its determinants. International Journal of Mathematical Models and Methods in Applied Sciences, 5(6), 1060-1067.

Winograd, L. P. B. M. (1999). The PageRank Citation Ranking: Bringing Order to the We. Technical 
Report. Stanford InfoLab, 9(1), 1-14. 
Table 1: Distribution of banks and representativeness of the final sample

\begin{tabular}{|c|c|c|c|}
\hline Countries & $\begin{array}{l}\text { Number of } \\
\text { banks in our } \\
\text { final sample }\end{array}$ & $\begin{array}{c}\text { Number of } \\
\text { banks in } \\
\text { Bankscope }\end{array}$ & $\begin{array}{l}\text { Percent of } \\
\text { total assets } \\
\text { (\%) }\end{array}$ \\
\hline AUSTRIA & 87 & 102 & 91.61 \\
\hline BELGIUM & 29 & 38 & 98.39 \\
\hline BULGARIA & 19 & 24 & 77.17 \\
\hline CROATIA & 30 & 38 & 92.67 \\
\hline CYPRUS & 13 & 26 & 94.08 \\
\hline CZECH REPUBLIC & 24 & 29 & 90.56 \\
\hline DENMARK & 45 & 52 & 98.45 \\
\hline ESTONIA & 9 & 11 & 98.07 \\
\hline FINLAND & 28 & 34 & 97.30 \\
\hline FRANCE & 137 & 173 & 87.19 \\
\hline GERMANY & 184 & 215 & 89.44 \\
\hline GREECE & 14 & 17 & 87.27 \\
\hline HUNGARY & 27 & 39 & 95.26 \\
\hline IRELAND & 22 & 38 & 81.94 \\
\hline ITALY & 105 & 132 & 76.15 \\
\hline LATVIA & 23 & 25 & 84.31 \\
\hline LITHUANIA & 11 & 12 & 90.36 \\
\hline LUXEMBOURG & 61 & 81 & 92.39 \\
\hline MALTA & 9 & 17 & 88.18 \\
\hline NETHERLANDS & 33 & 50 & 74.62 \\
\hline POLAND & 34 & 54 & 83.60 \\
\hline PORTUGAL & 23 & 34 & 88.87 \\
\hline ROMANIA & 20 & 27 & 91.52 \\
\hline SLOVAKIA & 12 & 17 & 88.08 \\
\hline SLOVENIA & 14 & 18 & 94.89 \\
\hline SPAIN & 41 & 70 & 94.23 \\
\hline SWEDEN & 37 & 44 & 98.27 \\
\hline $\begin{array}{l}\text { UNITED } \\
\text { KINGDOM }\end{array}$ & 237 & 297 & 85.09 \\
\hline Total & 1328 & 1714 & 88.42 \\
\hline
\end{tabular}


Table 2: Descriptive Statistics on our Dependents, Network and Control variables

\begin{tabular}{|l|r|r|r|r|r|}
\hline Variables & \multicolumn{1}{l|}{ Mean } & \multicolumn{1}{l|}{ Sd } & \multicolumn{1}{l|}{ Min } & \multicolumn{1}{l}{ Median } \\
\hline NSFR & 0,811 & 0,653 & 0,046 & 0,751 & 2,449 \\
\hline NL_DSTF & 72,476 & 44,227 & 5,137 & 72,731 & 180,099 \\
\hline In-Degree & 1,776 & 3,480 & 0,000 & 1,000 & 61,000 \\
\hline Out-Degree & 1,775 & 3,057 & 0,000 & 1,000 & 55,000 \\
\hline ClusteringCo & 0,186 & 0,299 & 0,000 & 0,000 & 1,000 \\
\hline Hub & 0,026 & 0,041 & 0,000 & 0,010 & 0,429 \\
\hline Authority & 0,026 & 0,043 & 0,000 & 0,009 & 0,600 \\
\hline Betweenness & 0,047 & 0,128 & 0,000 & 0,002 & 1,000 \\
\hline Closeness & 0,317 & 0,135 & 0,000 & 0,292 & 1,000 \\
\hline PageRank & 0,026 & 0,052 & 0,000 & 0,008 & 0,487 \\
\hline Bank-Size & 14,472 & 2,172 & 3,397 & 14,274 & 21,513 \\
\hline Z-Score & 69,456 & 80,357 & 3,284 & 38,345 & 311,580 \\
\hline NIM & 2,393 & 1,805 & 0,132 & 1,983 & 7,026 \\
\hline ROA & 0,671 & 1,179 & $-1,942$ & 0,503 & 3,597 \\
\hline Cost_Inc & 64,892 & 23,844 & 21,563 & 64,002 & 118,519 \\
\hline Eq_TA & 12,543 & 12,775 & 2,050 & 8,012 & 53,252 \\
\hline hhi_TA & 0,190 & 0,113 & 0,054 & 0,168 & 0,841 \\
\hline CB_PolicyR & 2,490 & 1,541 & 0,000 & 2,500 & 7,750 \\
\hline LogGDPperCAP & 27,183 & 1,624 & 22,139 & 27,914 & 30,790 \\
\hline Inflation & 2,656 & 3,537 & $-4,480$ & 2,109 & 59,097 \\
\hline Banking sector & 0,267 & 0,318 & $1.44 \mathrm{E}-04$ & 0,162 & 1,710 \\
size & & & & & \\
\hline
\end{tabular}

This table presents descriptive statistics of our variables: NSFR= Net Stable Funding Ratio; NL_DSTF= Net Loans to Deposits and Short-term funds; Network variables= InDegree, OutDegree, ClusteringCo, Hub, Authority, Betweenness, Closeness, PageRank; NIM= Net Interest Margin; ROA= Return on Assets; Cost_Inc $=$ Cost-income ratio; Eq_TA = Equity to total assets; hhi_TA= Herfindahl-Hirschman Index; CB_PolicyR= Central bank policy rate; LogGDPperCAP = natural log of GDP per capita; Inflation; Banking sector size. All Dependent and bank-level control variables are winsorized at 5\% $95 \%$ except network variables. 
Table 3: Stylized Balance Sheet and Weights to Compute the NSFR

\begin{tabular}{|c|c|c|c|}
\hline ASSETS & Weight & LIABILITIES+EQUITY & Weight \\
\hline $\begin{array}{l}\text { 1 Total Earning Assets } \\
\text { 1.A Loans } \\
\text { 1.A.1 Total Customer Loans } \\
\text { Mortgages Loans } \\
\text { Other Mortgage Loans } \\
\text { Other Consumer/Retail Loans } \\
\text { Corporate \&Commercial Loans } \\
\text { Other Loans } \\
\text { 1.A.2 Reserves for Impaired Loans/NPLs } \\
\text { 1.B Other Earning Assets } \\
\text { 1.B.1 Loans and Advances to Banks } \\
\text { 1.B.2 Derivatives } \\
\text { 1.B.3 Other Securities } \\
\text { Trading securities } \\
\text { Investment securities } \\
\text { 1.B.4 Remaining earning assets } \\
\text { 2 Fixed Assets } \\
\text { 3 Non-Earning Assets } \\
\text { 3.A Cash and due from banks } \\
\text { 3.B Goodwill } \\
\text { 3.C Other Intangibles } \\
\text { 3.D Other Assets }\end{array}$ & $\begin{array}{l}0 \% \\
100 \% \\
100 \% \\
100 \%\end{array}$ & $\begin{array}{l}\text { 1 Deposits \&Short-term funding } \\
\text { 1.A Customer Deposits } \\
\text { 1.A.1 Customer Deposits- Current } \\
\text { 1.A.2 Customer Deposits-Savings } \\
\text { 1.A.3 Customer Deposits-Term } \\
\text { 1.B Deposits from Banks } \\
\text { 1.C Other Deposits and Short-term Borrowings } \\
\text { 2 Other interest bearing liabilities } \\
\text { 2.A Derivatives } \\
\text { 2.B Trading Liabilities } \\
\text { 2.C Long-term funding } \\
\text { 2.C.1 Total Long Term Funding } \\
\text { Senior Debt } \\
\text { Subordinated Borrowing } \\
\text { Other Funding } \\
\text { 2.C.2 Pref. Shares and Hybrid Capital } \\
\text { 3 Other (Non-Interest bearing) } \\
\text { 4 Loan Loss Reserves } \\
5 \text { Other Reserves } \\
\text { 6 Equity }\end{array}$ & $\begin{array}{c}85 \% \\
70 \% \\
70 \% \\
0 \% \\
0 \%\end{array}$ \\
\hline
\end{tabular}

This table presents a stylized bank balance sheet, together with the weights assigned to different assets and liabilities for the computation of the net stable funding ratio. 
Table 4: Baseline Instrumental Variable model of network effects on bank's Structural liquidity (NSFR)

\begin{tabular}{|c|c|c|c|c|c|c|c|c|}
\hline & (1) & (2) & (3) & (4) & (5) & (6) & (7) & (8) \\
\hline & NSFR & NSFR & NSFR & NSFR & NSFR & NSFR & NSFR & NSFR \\
\hline \multirow[t]{2}{*}{$\log T A$} & $-0.0894^{* * *}$ & $-0.0983^{* * *}$ & $-0.0880^{* * *}$ & $-0.0855^{* * *}$ & $-0.0857^{* * *}$ & $-0.0819^{* * *}$ & $-0.0960^{* * *}$ & $-0.0841^{* * *}$ \\
\hline & $(0.0146)$ & $(0.0145)$ & $(0.0153)$ & $(0.0147)$ & $(0.0146)$ & $(0.0152)$ & $(0.0165)$ & $(0.0150)$ \\
\hline \multirow[t]{2}{*}{ Z-Score } & $-0.000117^{* *}$ & $-0.000124^{* *}$ & $-0.000132 * *$ & $-0.000115^{* *}$ & $-0.000121^{* *}$ & $-0.000110^{* *}$ & -0.0000859 & $-0.000116^{* *}$ \\
\hline & $(0.0000526)$ & $(0.0000527)$ & $(0.0000563)$ & $(0.0000532)$ & $(0.0000530)$ & $(0.0000547)$ & $(0.0000686)$ & $(0.0000534)$ \\
\hline \multirow[t]{2}{*}{ NIM } & $-0.0190 * * *$ & $-0.0175^{* *}$ & $-0.0215^{* * *}$ & $-0.0190 * * *$ & $-0.0188^{* * *}$ & $-0.0228^{* * *}$ & $-0.0233^{* * *}$ & $-0.0208^{* * *}$ \\
\hline & $(0.00680)$ & $(0.00679)$ & $(0.00722)$ & $(0.00684)$ & $(0.00681)$ & $(0.00704)$ & $(0.00859)$ & $(0.00691)$ \\
\hline \multirow[t]{2}{*}{ ROA } & $0.0283^{* * *}$ & $0.0281 * * *$ & $0.0268^{* * *}$ & $0.0283^{* * *}$ & $0.0280 * * *$ & $0.0311^{* * *}$ & $0.0266^{* * *}$ & $0.0283^{* * *}$ \\
\hline & $(0.00691)$ & $(0.00693)$ & $(0.00738)$ & $(0.00695)$ & $(0.00693)$ & $(0.00709)$ & $(0.00809)$ & $(0.00699)$ \\
\hline \multirow[t]{2}{*}{ Cost_Inc } & $-0.00119 * * *$ & $-0.00115^{* * *}$ & $-0.00113^{* * *}$ & $-0.00119 * * *$ & $-0.00121 * * *$ & $-0.00120^{* * *}$ & $-0.00147^{* * *}$ & $-0.00122 * * *$ \\
\hline & $(0.000408)$ & $(0.000408)$ & $(0.000423)$ & $(0.000408)$ & $(0.000407)$ & $(0.000414)$ & $(0.000493)$ & $(0.000410)$ \\
\hline \multirow[t]{2}{*}{ L.Eq_TA } & $0.00625 * * *$ & $0.00614^{* * *}$ & $0.00647^{* * *}$ & $0.00642 * * *$ & $0.00636^{* * *}$ & $0.00648^{* * *}$ & $0.00646 * * *$ & $0.00639^{* * *}$ \\
\hline & $(0.00127)$ & $(0.00127)$ & $(0.00132)$ & $(0.00127)$ & $(0.00127)$ & $(0.00129)$ & $(0.00150)$ & $(0.00128)$ \\
\hline \multirow[t]{2}{*}{ CB_Policyrate } & $0.0189 * * *$ & $0.0175^{* * *}$ & $0.0163^{* * *}$ & $0.0173^{* * *}$ & $0.0176^{* * *}$ & $0.0175^{* * *}$ & $0.0251 * * *$ & $0.0176^{* * *}$ \\
\hline & $(0.00375)$ & $(0.00376)$ & $(0.00407)$ & $(0.00376)$ & $(0.00375)$ & $(0.00381)$ & $(0.00527)$ & $(0.00377)$ \\
\hline \multirow[t]{2}{*}{ LogGDPperCap } & $0.171^{*}$ & $0.210^{* *}$ & $0.189 * *$ & 0.0581 & 0.0810 & -0.0150 & 0.0752 & 0.0680 \\
\hline & $(0.0879)$ & $(0.0875)$ & $(0.0915)$ & $(0.0971)$ & $(0.0924)$ & $(0.106)$ & $(0.126)$ & $(0.0967)$ \\
\hline \multirow[t]{2}{*}{ Inflation } & $-0.00577^{* *}$ & $-0.00616^{* *}$ & $-0.00617 * *$ & -0.00427 & $-0.00472^{*}$ & $-0.00679^{* * *}$ & 0.000370 & $-0.00447^{*}$ \\
\hline & $(0.00255)$ & $(0.00257)$ & $(0.00273)$ & $(0.00264)$ & $(0.00258)$ & $(0.00258)$ & $(0.00500)$ & $(0.00262)$ \\
\hline \multirow[t]{2}{*}{ Sector-Size/GDP } & $0.517^{* * *}$ & $0.530^{* * *}$ & $0.511^{* * *}$ & $0.510^{* * *}$ & $0.510^{* * *}$ & $0.521 * * *$ & $0.330^{* * *}$ & $0.507^{* * *}$ \\
\hline & $(0.0646)$ & $(0.0648)$ & $(0.0668)$ & $(0.0646)$ & $(0.0646)$ & $(0.0657)$ & $(0.105)$ & $(0.0650)$ \\
\hline \multirow[t]{2}{*}{ hhi_TA } & $-0.284^{* *}$ & $-0.286^{* *}$ & $-0.324^{* *}$ & -0.122 & -0.156 & $-0.268^{* *}$ & 0.410 & -0.153 \\
\hline & $(0.128)$ & $(0.128)$ & $(0.136)$ & $(0.137)$ & $(0.132)$ & $(0.131)$ & $(0.314)$ & $(0.136)$ \\
\hline \multirow[t]{2}{*}{ investment } & $0.299 * * *$ & $0.297^{* * *}$ & $0.354^{* * *}$ & $0.361^{* * *}$ & $0.367^{* * *}$ & $0.341^{* * *}$ & $0.338^{* *}$ & $0.366^{* * *}$ \\
\hline & $(0.101)$ & $(0.0988)$ & $(0.106)$ & $(0.122)$ & $(0.121)$ & $\begin{array}{l}(0.12 \\
7)\end{array}$ & $(0.140)$ & $(0.128)$ \\
\hline \multirow{2}{*}{ realestate } & -0.254 & -0.250 & -0.188 & -0.255 & -0.253 & -0.257 & -0.362 & -0.253 \\
\hline & $(0.215)$ & $(0.214)$ & $(0.223)$ & $(0.215)$ & $(0.215)$ & $(0.214)$ & $(0.247)$ & $(0.216)$ \\
\hline \multirow[t]{2}{*}{ crisis_subprime } & $-0.0434 * * *$ & $-0.0405 * * *$ & $-0.0350 * *$ & $-0.0364 * * *$ & $-0.0379 * * *$ & $-0.0346 * *$ & $-0.0576^{* * *}$ & $-0.0385 * * *$ \\
\hline & $(0.0133)$ & $(0.0132)$ & $(0.0145)$ & $(0.0134)$ & $(0.0133)$ & $(0.0137)$ & $(0.0180)$ & $(0.0134)$ \\
\hline \multirow[t]{2}{*}{ crisis_sovereign } & $-0.0485^{* * *}$ & $-0.0474^{* * *}$ & $-0.0428^{* * *}$ & $-0.0491^{* * *}$ & $-0.0485^{* * *}$ & $-0.0470^{* * *}$ & $-0.0981^{* * *}$ & $-0.0501^{* * *}$ \\
\hline & $(0.0103)$ & $(0.0103)$ & $(0.0111)$ & $(0.0104)$ & $(0.0104)$ & $(0.0106)$ & $(0.0231)$ & $(0.0105)$ \\
\hline \multirow[t]{2}{*}{ InDegree } & $-0.0124 * * *$ & & & & & & & \\
\hline & $(0.00359)$ & & & & & & & \\
\hline \multirow[t]{2}{*}{ OutDegree } & & $0.0127^{* * *}$ & & & & & & \\
\hline & & $(0.00455)$ & & & & & & \\
\hline \multirow[t]{2}{*}{ ClusteringCoefficient } & & & $0.400^{* *}$ & & & & & \\
\hline & & & $(0.185)$ & & & & & \\
\hline Hub & & & & $-3.002 * * *$ & & & & \\
\hline & & & & $(0.847)$ & & & & \\
\hline Authority & & & & & $-2.356^{* * *}$ & & & \\
\hline & & & & & $(0.494)$ & & & \\
\hline BetweennessCentrality & & & & & & $-1.053^{* * *}$ & & \\
\hline & & & & & & $(0.260)$ & & \\
\hline ClosenessCentrality & & & & & & & $-2.785^{* * *}$ & \\
\hline & & & & & & & (1.069) & \\
\hline PageRank & & & & & & & & $-2.341^{* * *}$ \\
\hline & & & & & & & & $(0.670)$ \\
\hline Total Obs. & 11254 & 11254 & 11254 & 11254 & 11254 & 11236 & 11236 & 11199 \\
\hline No. Of Banks & 1271 & 1271 & 1271 & 1271 & 1271 & 1271 & 1271 & 1268 \\
\hline Hansen test $F$ & 1.242 & 0.345 & 1.963 & 2.173 & 0.568 & 3.426 & 3.235 & 0.717 \\
\hline Hansen test P-Value & 0.537 & 0.841 & 0.161 & 0.140 & 0.451 & 0.180 & 0.198 & 0.397 \\
\hline Under-Ident rk-LM test & 86.97 & 47.45 & 38.86 & 44.86 & 69.96 & 40.73 & 9.885 & 31.78 \\
\hline Under-Ident rk-LM test & $9.79 \mathrm{e}-19$ & $2.79 \mathrm{e}-10$ & $3.64 \mathrm{e}-09$ & $1.81 \mathrm{e}-10$ & $6.43 e-16$ & $7.45 e-09$ & 0.0196 & 0.000000125 \\
\hline
\end{tabular}

This table presents the baseline regression results using Instrumental Variables for an unbalanced panel of European Commercial, Investment and Real-estate banks over the 2001-2013 period. We employ IV estimator with bank-specific fixed effect to estimate the following equation:

$\operatorname{NSFR}_{i, t}=\alpha_{0}+\alpha_{1} \operatorname{Netw}(x)_{i, t}+\alpha_{2} B_{i, t}+\alpha_{3} B_{i, t-1}+\alpha_{4} C_{i, t}+\alpha_{5}$ Crisis_subprime $_{t}+\alpha_{6}$ Crisis_sovereign $_{t}+\alpha_{7}$ Investment $_{i}+\alpha_{8}$ Realestate $_{i}+\mu_{\mathrm{i}, \mathrm{t}}+\varepsilon_{i, t}$

Dependent variable is NSFR. Network statistics are our main independent variables including In-Degree, Out-Degree, Clustering Coefficient, Hub, Authority, Betweenness, Closeness and PageRank. Because of high correlation between our network variables, we estimate them by separate equations. $\mathrm{B}_{\mathrm{i}, \mathrm{t}}$ is a vector of bank level control variables including Bank-Size, Z-score, Net interest margin, Return on assets and Cost-income ratio. $\mathrm{B}_{\mathrm{i}, \mathrm{t}-\mathrm{1}}$ is one year lagged value of Equity to total assets. $\mathrm{C}_{\mathrm{i}}$ is a vector of country-level control variables that includes CB policy Rate, log GDP per capita, inflation, banking sector size and HHI index. Crisis_Subprime and Crisis_Sovereign are dummy variables for Subprime crisis and sovereign crisis respectively. Investment and realestate are bank specialization dummy variables. The 


\section{Table 5: Instrumental Variable model of network effects on bank's Structural liquidity during Subprime Mortgage Crisis}

\begin{tabular}{|c|c|c|c|c|c|c|c|c|}
\hline & (1) & $(2)$ & (3) & (4) & (5) & (6) & (7) & (8) \\
\hline & NSFR & NSFR & NSFR & NSFR & NSFR & NSFR & NSFR & NSFR \\
\hline \multirow[t]{2}{*}{ crisis_subprime } & $-0.0357 * *$ & $-0.0310 * *$ & 0.0527 & $-0.0408 * * *$ & $-0.0397 * * *$ & $-0.0370 * * *$ & $-0.169 * * *$ & $-0.0464 * * *$ \\
\hline & $(0.0144)$ & $(0.0144)$ & $(0.0416)$ & $(0.0147)$ & $(0.0145)$ & $(0.0137)$ & $(0.0549)$ & $(0.0145)$ \\
\hline \multirow[t]{2}{*}{ InDegree } & $-0.0125^{* * *}$ & & & & & & & \\
\hline & $(0.00371)$ & & & & & & & \\
\hline \multirow[t]{2}{*}{ InDegree*crisis_subprime } & $-0.00445^{* *}$ & & & & & & & \\
\hline & $(0.00227)$ & & & & & & & \\
\hline \multirow[t]{2}{*}{ OutDegree } & & $0.0132 * * *$ & & & & & & \\
\hline & & $(0.00464)$ & & & & & & \\
\hline \multirow[t]{2}{*}{ OutDegree*crisis_subprime } & & $-0.00533 * *$ & & & & & & \\
\hline & & $(0.00249)$ & & & & & & \\
\hline \multirow[t]{2}{*}{ ClusteringCoefficient } & & & $0.474 * *$ & & & & & \\
\hline & & & $(0.216)$ & & & & & \\
\hline \multirow[t]{2}{*}{ ClusteringCo*crisis_subprime } & & & $-0.484^{* *}$ & & & & & \\
\hline & & & $(0.199)$ & & & & & \\
\hline \multirow[t]{2}{*}{ Hub } & & & & $-2.991 * * *$ & & & & \\
\hline & & & & $(0.810)$ & & & & \\
\hline \multirow[t]{2}{*}{ Hub* Subprime } & & & & 0.162 & & & & \\
\hline & & & & $(0.266)$ & & & & \\
\hline \multirow[t]{2}{*}{ Authority } & & & & & $-2.354 * * *$ & & & \\
\hline & & & & & $(0.490)$ & & & \\
\hline \multirow[t]{2}{*}{ Auth*Subprime } & & & & & 0.0505 & & & \\
\hline & & & & & $(0.215)$ & & & \\
\hline \multirow[t]{2}{*}{ BetweennessCentrality } & & & & & & $-1.069 * * *$ & & \\
\hline & & & & & & $(0.262)$ & & \\
\hline \multirow[t]{2}{*}{ Betweenness*crisis_subprime } & & & & & & $0.00423^{*}$ & & \\
\hline & & & & & & (0.00219) & & \\
\hline \multirow[t]{2}{*}{ ClosenessCentrality } & & & & & & & $-3.282 * *$ & \\
\hline & & & & & & & $(1.322)$ & \\
\hline \multirow[t]{2}{*}{ Closeness*crisis_subprime } & & & & & & & $0.310 * *$ & \\
\hline & & & & & & & $(0.131)$ & \\
\hline \multirow[t]{2}{*}{ PageRank } & & & & & & & & $-2.311 * * *$ \\
\hline & & & & & & & & $(0.639)$ \\
\hline \multirow[t]{2}{*}{ PageRank*crisis_subprime } & & & & & & & & 0.313 \\
\hline & & & & & & & & $(0.240)$ \\
\hline \multirow[t]{2}{*}{$\alpha_{1}+\alpha_{6}$} & $-.0169 * * *$ & $.0078^{* *}$ & -.01001 & $-2.829 * * *$ & $-2.302 * * *$ & $-1.064 * * *$ & $-2.972 * *$ & $-1.997 * * *$ \\
\hline & $(.0038)$ & $(.0078)$ & $(.0373)$ & $(.6640)$ & $(.4028)$ & $(.2603)$ & $(1.202)$ & $(.4744)$ \\
\hline Bank Level Control & Yes & Yes & Yes & Yes & Yes & Yes & Yes & Yes \\
\hline Country Level Control & Yes & Yes & Yes & Yes & Yes & Yes & Yes & Yes \\
\hline Bank Specialization Dummy & Yes & Yes & Yes & Yes & Yes & Yes & Yes & Yes \\
\hline Sovereign Crisis Dummy & Yes & Yes & Yes & Yes & Yes & Yes & Yes & Yes \\
\hline Total Obs. & 11254 & 11254 & 11254 & 11254 & 11254 & 11236 & 11236 & 11199 \\
\hline No. Of Banks & 1271 & 1271 & 1271 & 1271 & 1271 & 1271 & 1271 & 1268 \\
\hline HansenTest F & 1.257 & 0.165 & 2.034 & 1.966 & 0.567 & 4.785 & 2.139 & 0.542 \\
\hline Hansen P-Value & 0.533 & 0.921 & 0.154 & 0.161 & 0.452 & 0.0914 & 0.343 & 0.462 \\
\hline Under-Ident rk-LM test & 87.87 & 43.80 & 34.69 & 50.28 & 71.73 & 41.18 & 8.227 & 35.17 \\
\hline Under-Ident rk-LM test P-Value & $6.29 e-19$ & $1.67 e-09$ & $2.93 e-08$ & $1.21 \mathrm{e}-11$ & $2.65 e-16$ & $5.98 e-09$ & 0.0416 & $2.30 \mathrm{e}-08$ \\
\hline
\end{tabular}

This table presents regression results using Instrumental Variables for an unbalanced panel of European Commercial, Investment and Real-estate banks over the 2001-2013 period introducing the interaction between the subprime dummy variable and the network variable. We employ IV estimator with bank-specific fixed effect to estimate the following equation:

$\operatorname{NSFR}_{i, t}=\alpha_{0}+\alpha_{1} \operatorname{Netw}(x)_{i, t}+\alpha_{2} B_{i, t}+\alpha_{3} B_{i, t-1}+\alpha_{4} C_{i, t}+\alpha_{5}$ Crisis_subprime $_{t}+\alpha_{6}$ Crisis_subprime $_{t} *$ Netw $_{-}(x)_{i, t}+\alpha_{7}$ Investment $_{i}+\alpha_{8}$ Realestate $_{i}+\mu_{i, t}+\varepsilon_{i, t}$ 
Dependent variable is NSFR. Network statistics are our main independent variables including In-Degree, Out-Degree, Clustering Coefficient, Hub, Authority, Betweenness, Closeness and PageRank. Because of high correlation between our network variables, we estimate them by separate equations. $\mathrm{B}_{\mathrm{i}, \mathrm{t}}$ is a vector of bank level control variables including Bank-Size, Z-score, Net interest margin, Return on assets and Cost-income ratio. $\mathrm{B}_{\mathrm{i}, \mathrm{t}-1}$ is one year lagged value of Equity to total assets. $\mathrm{C}_{\mathrm{i}}$ is a vector of country-level control variables that includes CB policy Rate, log GDP per capita, inflation, banking sector size and HHI index. Crisis_Subprime is a dummy variable for Subprime crisis. Investment and real estate are bank specialization dummy variables. Netw(x)*Crisis Subprime is the interaction between our network variables and the subprime dummy variable. We test the impact of the network variables during the subprime crisis with $\left(\alpha_{1}+\alpha_{6}\right)$.The Kleibergen-Paap rank LM statistic (Under-Ident rk-LM test) is an underidentification test, to reject the null hypothesis that the equation is underidentified. Hansen Test $\mathrm{F}$ is an overidentification test to reject the null hypothesis that the equation is overidentified. All Dependent and bank-level control variables are winsorized at 5\% - 95\% except network variables. Standard errors are shown in parentheses. *, **, *** indicate significance at the $10 \%, 5 \%$, and $1 \%$ level, respectiv 
Table 6: Instrumental Variable model of network effects on bank's Structural liquidity during European Sovereign Crisis

\begin{tabular}{|c|c|c|c|c|c|c|c|c|}
\hline & (1) & (2) & (3) & (4) & (5) & (6) & (7) & $(8)$ \\
\hline & NSFR & NSFR & NSFR & NSFR & NSFR & NSFR & NSFR & NSFR \\
\hline \multirow[t]{2}{*}{ crisis_sovereign } & $-0.0430 * * *$ & $-0.0396 * * *$ & 0.0166 & $-0.0574 * * *$ & $-0.0559 * * *$ & $-0.0476 * * *$ & $-0.162 * * *$ & $-0.0512^{* * *}$ \\
\hline & $(0.0117)$ & $(0.0116)$ & $(0.0343)$ & $(0.0127)$ & $(0.0123)$ & $(0.0106)$ & $(0.0459)$ & $(0.0107)$ \\
\hline \multirow{2}{*}{ InDegree } & $-0.0129 * * *$ & & & & & & & \\
\hline & $(0.00370)$ & & & & & & & \\
\hline \multirow[t]{2}{*}{ InDegree*crisis_sovereign } & $-0.00331 * *$ & & & & & & & \\
\hline & $(0.00162)$ & & & & & & & \\
\hline \multirow[t]{2}{*}{ OutDegree } & & $0.0122 * * *$ & & & & & & \\
\hline & & $(0.00461)$ & & & & & & \\
\hline \multirow[t]{2}{*}{ OutDegree*crisis_sovereign } & & $-0.00444^{* *}$ & & & & & & \\
\hline & & $(0.00190)$ & & & & & & \\
\hline \multirow[t]{2}{*}{ ClusteringCoefficient } & & & $0.409 * *$ & & & & & \\
\hline & & & $(0.202)$ & & & & & \\
\hline \multirow[t]{2}{*}{ ClusteringCo*crisis_sovereign } & & & $-0.364 * *$ & & & & & \\
\hline & & & $(0.186)$ & & & & & \\
\hline \multirow[t]{2}{*}{ Hub } & & & & $-3.029 * * *$ & & & & \\
\hline & & & & $(0.867)$ & & & & \\
\hline \multirow[t]{2}{*}{ Hub*crisis_sovereign } & & & & 0.316 & & & & \\
\hline & & & & $(0.241)$ & & & & \\
\hline \multirow[t]{2}{*}{ Authority } & & & & & $-2.371 * * *$ & & & \\
\hline & & & & & $(0.502)$ & & & \\
\hline \multirow[t]{2}{*}{ Auth*crisis_sovereign } & & & & & 0.274 & & & \\
\hline & & & & & $(0.202)$ & & & \\
\hline \multirow[t]{2}{*}{ BetweennessCentrality } & & & & & & $-1.076 * * *$ & & \\
\hline & & & & & & $(0.264)$ & & \\
\hline \multirow[t]{2}{*}{ Betweenness*crisis_sovereign } & & & & & & -0.0000444 & & \\
\hline & & & & & & $(0.00110)$ & & \\
\hline \multirow[t]{2}{*}{ ClosenessCentrality } & & & & & & & $-2.743 * * *$ & \\
\hline & & & & & & & $(1.018)$ & \\
\hline \multirow[t]{2}{*}{ Closeness*crisis_sovereign } & & & & & & & $0.200 * *$ & \\
\hline & & & & & & & $(0.0878)$ & \\
\hline \multirow[t]{2}{*}{ PageRank } & & & & & & & & $-2.331 * * *$ \\
\hline & & & & & & & & $(0.674)$ \\
\hline \multirow[t]{2}{*}{ PageRank*crisis_sovereign } & & & & & & & & 0.00397 \\
\hline & & & & & & & & $(0.00788)$ \\
\hline \multirow[t]{2}{*}{$\alpha_{1}+\alpha_{6}$} & $-.016 * * *$ & $.0077^{*}$ & .0445 & $-2.712 * * *$ & $-2.096 * * *$ & $-1.076 * * *$ & $-2.542 * * *$ & $-2.327^{* * *}$ \\
\hline & $(.0037)$ & $(.0042)$ & $(.0417)$ & $(-2.712)$ & $(.4697)$ & $(.264)$ & $(.9485)$ & $(.6748)$ \\
\hline Bank Level Control & Yes & Yes & Yes & Yes & Yes & Yes & Yes & Yes \\
\hline Country Level Control & Yes & Yes & Yes & Yes & Yes & Yes & Yes & Yes \\
\hline Bank Specialization Dummy & Yes & Yes & Yes & Yes & Yes & Yes & Yes & Yes \\
\hline Subprime Crisis Dummy & Yes & Yes & Yes & Yes & Yes & Yes & Yes & Yes \\
\hline Total Obs. & 11254 & 11254 & 11254 & 11254 & 11254 & 11236 & 11236 & 11199 \\
\hline No. Of Banks & 1271 & 1271 & 1271 & 1271 & 1271 & 1271 & 1271 & 1268 \\
\hline Hansen Test $F$ & 1.194 & 0.564 & 2.691 & 1.919 & 0.645 & 4.730 & 3.361 & 0.697 \\
\hline Hansen P-Value & 0.551 & 0.754 & 0.101 & 0.166 & 0.422 & 0.0940 & 0.186 & 0.404 \\
\hline Under-Ident rk-LM test & 87.07 & 49.28 & 36.12 & 43.45 & 67.91 & 40.34 & 10.69 & 31.43 \\
\hline Under-Ident rk-LM test P-Value & $9.31 \mathrm{e}-19$ & $1.14 \mathrm{e}-10$ & $1.43 e-08$ & $3.67 e-10$ & $1.80 \mathrm{e}-15$ & $9.05 e-09$ & 0.0135 & 0.000000150 \\
\hline
\end{tabular}

This table presents regression results using Instrumental Variables for an unbalanced panel of European Commercial, Investment and Real-estate banks over the 2001-2013 period introducing the interaction between the sovereign crisis dummy variable and the network variable. We employ IV estimator with bank-specific fixed effect to estimate the following equation:

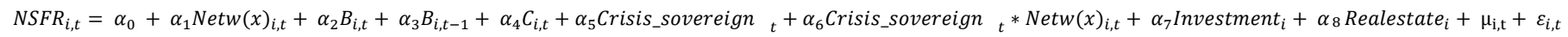

Dependent variable is NSFR. Network statistics are our main independent variables including In-Degree, Out-Degree, Clustering Coefficient, Hub, Authority, Betweenness, Closeness and PageRank. Because of high correlation between our network variables, we estimate them by separate equations. $\mathrm{B}_{\mathrm{i}, \mathrm{t}}$ is a vector of bank level control variables including Bank-Size, $\mathrm{Z}$-score, Net interest margin, Return on assets and Cost-income ratio. $\mathrm{B}_{\mathrm{i}, \mathrm{t}-\mathrm{1}}$ is one year lagged value of Equity to total assets. $\mathrm{C}_{\mathrm{i}}$ is a vector of country-level control variables that includes CB policy Rate, log GDP per capita, inflation, banking sector size and HHI index. Crisis_Sovereignis a dummy variable for Sovereign crisis. Investment and real estate are bank specialization dummy variables. Netw(x)*Crisis_sovereign is the interaction between our network variables and the sovereign crisis dummy variable. We test the impact of the network variables during the sovereign crisis with $\left(\alpha_{1}+\alpha_{6}\right)$.The Kleibergen-Paap rank LM statistic (Under-Ident rk-LM test) is an underidentification test, to reject the null hypothesis that the equation is underidentified. Hansen Test $\mathrm{F}$ is an overidentification test to reject the null hypothesis that the equation is overidentified. All Dependent and bank-level control variables are winsorized at 5\% - 95\% except network variables. Standard errors are shown in parentheses. *, **, *** indicate significance at the $10 \%, 5 \%$, and $1 \%$ level, respectively. 
Table 7: Instrumental Variable model of network effects on bank's Structural liquidity in Large and Small Banking Sector Size

\begin{tabular}{|c|c|c|c|c|c|c|c|c|}
\hline & $(1)$ & (2) & (3) & (4) & (5) & $(6)$ & (7) & (8) \\
\hline & NSFR & NSFR & NSFR & NSFR & NSFR & NSFR & NSFR & NSFR \\
\hline Sector-Size & $\begin{array}{l}-0.0237 \\
(0.0205)\end{array}$ & $\begin{array}{l}0.0108 \\
(0.0213)\end{array}$ & $\begin{array}{l}0.119 * \\
(0.0637)\end{array}$ & $-0.0636^{* * *}$ & $-0.0544^{* * *}$ & $\begin{array}{l}-0.0268 \\
(0.0189)\end{array}$ & $\begin{array}{l}-0.137^{*} \\
(0.0754)\end{array}$ & $\begin{array}{l}-0.0554 * * * \\
(0.0207)\end{array}$ \\
\hline InDegree & $\begin{array}{l}-0.0135^{* * *} \\
(0.00431)\end{array}$ & & & & & & & \\
\hline InDegree* Sector-Size & $\begin{array}{l}0.00220 \\
(0.00328)\end{array}$ & & & & & & & \\
\hline OutDegree & & $\begin{array}{l}0.0182 * * * \\
(0.00603)\end{array}$ & & & & & & \\
\hline OutDegree* Sector-Size & & $\begin{array}{l}-0.0135 * * * \\
(0.00450)\end{array}$ & & & & & & \\
\hline ClusteringCoefficient & & & $\begin{array}{l}0.712^{* *} \\
(0.326)\end{array}$ & & & & & \\
\hline ClusteringCo* Sector-Size & & & $\begin{array}{l}-0.728^{* *} \\
(0.325)\end{array}$ & & & & & \\
\hline Hub & & & & $\begin{array}{l}-3.197 * * * \\
(0.620)\end{array}$ & & & & \\
\hline Hub* Sector-Size & & & & $\begin{array}{l}2.201^{* * *} \\
(0.460)\end{array}$ & & & & \\
\hline Authority & & & & & $\begin{array}{l}-2.782^{* * *} \\
(0.521)\end{array}$ & & & \\
\hline Auth* Sector-Size & & & & & $\begin{array}{l}1.656^{* * *} \\
(0.410)\end{array}$ & & & \\
\hline BetweennessCentrality & & & & & & $\begin{array}{l}-1.076^{* * *} \\
(0.262)\end{array}$ & & \\
\hline Betweenness* Sector-Size & & & & & & $\begin{array}{l}0.165^{*} \\
(0.0937)\end{array}$ & & \\
\hline ClosenessCentrality & & & & & & & $\begin{array}{l}-3.080^{* * *} \\
(1.193)\end{array}$ & \\
\hline Closeness* Sector-Size & & & & & & & $\begin{array}{l}0.324 \\
(0.222)\end{array}$ & \\
\hline PageRank & & & & & & & & $\begin{array}{l}-2.693 * * * \\
(0.540)\end{array}$ \\
\hline PageRank* Sector-Size & & & & & & & & $\begin{array}{l}1.658^{* * *} \\
(0.401)\end{array}$ \\
\hline$\alpha_{1}+\alpha_{8}$ & $-.011 * * *$ & $.0047^{*}$ & -.0157 & $-.9959 * *$ & $-1.125 * * *$ & $-.9116 * * *$ & $-2.755^{* *}$ & $-1.035^{* * *}$ \\
\hline & $(.003)$ & $(.0028)$ & $(.0232)$ & $(.4369)$ & $(.3887)$ & $(.2495)$ & $(1.074)$ & $(.292)$ \\
\hline Bank Level Control & Yes & Yes & Yes & Yes & Yes & Yes & Yes & Yes \\
\hline Country Level Control & Yes & Yes & Yes & Yes & Yes & Yes & Yes & Yes \\
\hline Bank Specialization Dummy & Yes & Yes & Yes & Yes & Yes & Yes & Yes & Yes \\
\hline Crisis Period Dummy & Yes & Yes & Yes & Yes & Yes & Yes & Yes & Yes \\
\hline Total Obs. & 11254 & 11254 & 11254 & 11254 & 11254 & 11236 & 11236 & 11198 \\
\hline No. Of Banks & 1271 & 1271 & 1271 & 1271 & 1271 & 1271 & 1271 & 1268 \\
\hline HansenTest F & 0.182 & 0.460 & 1.420 & 1.919 & 0.468 & 3.763 & 2.761 & 0.276 \\
\hline Hansen P-Value & 0.670 & 0.794 & 0.233 & 0.383 & 0.494 & 0.152 & 0.251 & 0.599 \\
\hline Under-Ident rk-LM test & 70.72 & 30.19 & 22.60 & 74.37 & 87.12 & 41.14 & 9.216 & 50.61 \\
\hline $\begin{array}{l}\text { Under-Ident rk-LM test P- } \\
\text { Value }\end{array}$ & $4.39 e-16$ & 0.00000126 & 0.0000124 & $4.96 e-16$ & $1.21 \mathrm{e}-19$ & $6.12 \mathrm{e}-09$ & 0.0266 & $1.03 e-11$ \\
\hline
\end{tabular}

This table presents regression results using Instrumental Variables for an unbalanced panel of European Commercial, Investment and Real-estate banks over the 2001-2013 period introducing the interaction between the banking sector size crisis dummy variable and the network variable. We employ IV estimator with bankspecific fixed effect to estimate the following equation:

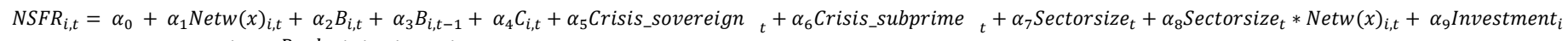
$+\alpha_{10}$ Realestate $_{i}+\mu_{\mathrm{i}, \mathrm{t}}+\varepsilon_{i, t}$

Dependent variable is NSFR. Network statistics are our main independent variables including In-Degree, Out-Degree, Clustering Coefficient, Hub, Authority, Betweenness, Closeness and PageRank. Because of high correlation between our network variables, we estimate them by separate equations. $\mathrm{B}_{\mathrm{i}, \mathrm{t}}$ is a vector of bank level control variables including Bank-Size, $\mathrm{Z}$-score, Net interest margin, Return on assets and Cost-income ratio. $\mathrm{B}_{\mathrm{i}, \mathrm{t}-\mathrm{i}}$ is one year lagged value of Equity to total assets. $\mathrm{C}_{\mathrm{i}}$ is a vector of country-level control variables that includes CB policy Rate, log GDP per capita, inflation, banking sector size and HHI index. Crisis_Subprime and Crisis_Sovereign are dummy variables for Subprime crisis and sovereign crisis respectively. Sector-size is a dummy variable that takes the value of one for large banking sector. Investment and real estate are bank specialization dummy variables. Netw $(\mathrm{x}) *$ Sectorsize is the interaction between our network variables and the large banking sector size dummy variable. We test the impact of the network variables for banks in large banking sector with $\left(\alpha_{1}+\alpha_{\mathbf{8}}\right)$.The Kleibergen-Paap rank LM 
Table 8: The Instrumental Variable model for All Banks' Specialization

\begin{tabular}{|c|c|c|c|c|c|c|c|c|}
\hline & (1) & (2) & (3) & (4) & (5) & (6) & (7) & (8) \\
\hline & NSFR & NSFR & NSFR & NSFR & NSFR & NSFR & NSFR & NSFR \\
\hline \multirow[t]{2}{*}{ InDegree } & $-0.0295 * * *$ & & & & & & & \\
\hline & $(0.00472)$ & & & & & & & \\
\hline \multirow[t]{2}{*}{ OutDegree } & & 0.00804 & & & & & & \\
\hline & & $(0.00516)$ & & & & & & \\
\hline \multirow[t]{2}{*}{ ClusteringCoefficient } & & & 0.0495 & & & & & \\
\hline & & & $(0.0505)$ & & & & & \\
\hline \multirow[t]{2}{*}{ Hub } & & & & $-5.213 * * *$ & & & & \\
\hline & & & & $(1.024)$ & & & & \\
\hline \multirow[t]{2}{*}{ Authority } & & & & & $-5.945^{* * *}$ & & & \\
\hline & & & & & $(0.981)$ & & & \\
\hline \multirow[t]{2}{*}{ BetweennessCentrality } & & & & & & -0.0236 & & \\
\hline & & & & & & $(0.0603)$ & & \\
\hline \multirow[t]{2}{*}{ ClosenessCentrality } & & & & & & & $-0.431 * * *$ & \\
\hline & & & & & & & $(0.116)$ & \\
\hline \multirow[t]{2}{*}{ PageRank } & & & & & & & & $-6.001 * * *$ \\
\hline & & & & & & & & $(1.229)$ \\
\hline Bank Level Control & Yes & Yes & Yes & Yes & Yes & Yes & Yes & Yes \\
\hline Country Level Control & Yes & Yes & Yes & Yes & Yes & Yes & Yes & Yes \\
\hline Bank Specialization Dummy & Yes & Yes & Yes & Yes & Yes & Yes & Yes & Yes \\
\hline Crises Dummy variables & Yes & Yes & Yes & Yes & Yes & Yes & Yes & Yes \\
\hline Hansen Test F & 0.185 & 0.134 & 0.911 & 0.492 & 2.222 & 0.283 & 1.575 & 1.973 \\
\hline HansenP-Value & 0.912 & 0.715 & 0.634 & 0.483 & 0.136 & 0.595 & 0.209 & 0.160 \\
\hline Under-Ident rk-LM test & 199.4 & 177.6 & 341.1 & 111.0 & 128.3 & 268.9 & 189.2 & 45.81 \\
\hline Under-Ident rk-LM test P-Value & $5.70 e-43$ & $2.69 \mathrm{e}-39$ & $1.25 e-73$ & $7.89 e-25$ & $1.41 \mathrm{e}-28$ & $4.06 e-59$ & $8.18 \mathrm{e}-42$ & $1.13 e-10$ \\
\hline
\end{tabular}

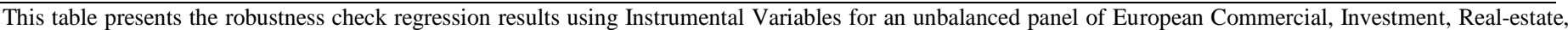
Cooperative and Savings banks over the 2001-2013 period. We employ IV estimator with bank-specific fixed effect to estimate the following equation:

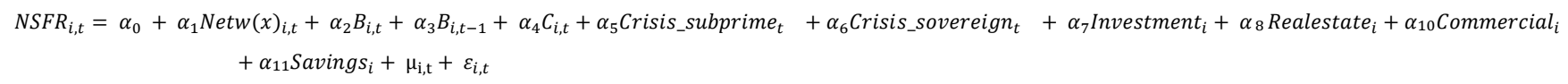

$$
+\alpha_{11} \text { Savings }_{i}+\mu_{\mathrm{i}, \mathrm{t}}+\varepsilon_{i, t}
$$

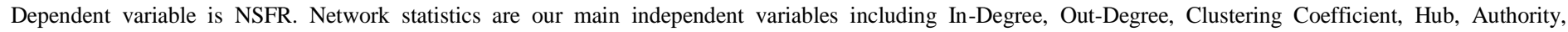

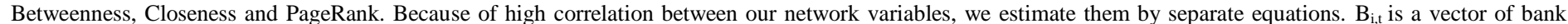

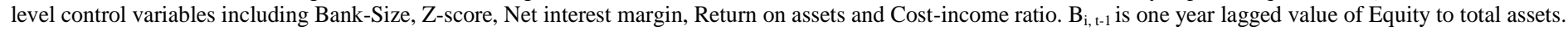

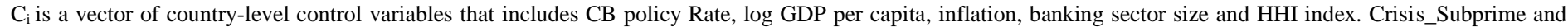

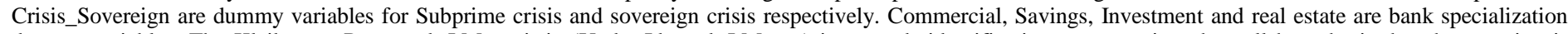

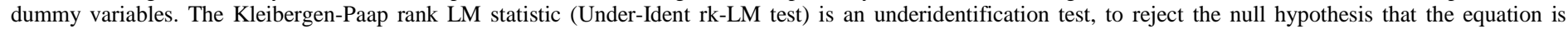

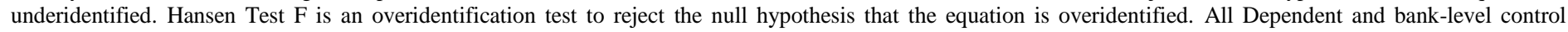

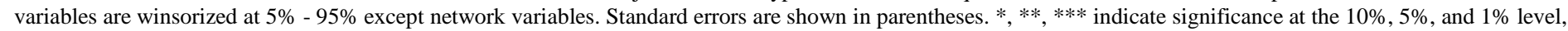
respectively. 


\section{Table 9: Instrumental Variable model of network effects on bank's alternative liquidity measurement}

\begin{tabular}{|c|c|c|c|}
\hline Network Variables & $\begin{array}{l}\text { (1) } \\
\text { NL_DSTF }\end{array}$ & $\begin{array}{l}\text { (2) } \\
\text { NL_TA }\end{array}$ & $\begin{array}{l}\mathbf{( 3 )} \\
\text { LA_DSTF }\end{array}$ \\
\hline InDegree & $\begin{array}{l}-0.813^{* * *} \\
(0.227)\end{array}$ & $\begin{array}{l}-0.181^{*} \\
(0.0992)\end{array}$ & $\begin{array}{l}-0.188 \\
(0.191)\end{array}$ \\
\hline OutDegree & $\begin{array}{l}-1.120^{* * *} \\
(0.251)\end{array}$ & $\begin{array}{l}-0.848^{* * *} \\
(0.177)\end{array}$ & $\begin{array}{l}1.323^{* * *} \\
(0.476)\end{array}$ \\
\hline ClusteringCoefficient & $\begin{array}{l}-11.04 \\
(8.492)\end{array}$ & $\begin{array}{l}-2.265 \\
(4.607)\end{array}$ & $\begin{array}{l}8.858 \\
(7.967)\end{array}$ \\
\hline Hub & $\begin{array}{l}-110.2^{* * *} \\
(31.17)\end{array}$ & $\begin{array}{l}-18.94 \\
(14.86)\end{array}$ & $\begin{array}{l}11.34 \\
(26.25)\end{array}$ \\
\hline Authority & $\begin{array}{l}-71.26^{* * *} \\
(23.72)\end{array}$ & $\begin{array}{l}-1.860 \\
(15.87)\end{array}$ & $\begin{array}{l}-8.046 \\
(20.64)\end{array}$ \\
\hline BetweennessCentrality & $\begin{array}{l}-110.4^{* * *} \\
(33.18)\end{array}$ & $\begin{array}{l}-38.87^{* * *} \\
(13.89)\end{array}$ & $\begin{array}{l}0.919 \\
(11.34)\end{array}$ \\
\hline ClosenessCentrality & $\begin{array}{l}-9.914 \\
(25.57)\end{array}$ & $\begin{array}{l}12.42 \\
(20.02)\end{array}$ & $\begin{array}{l}-45.89 \\
(32.35)\end{array}$ \\
\hline PageRank & $\begin{array}{l}-96.71^{* * *} \\
(27.59)\end{array}$ & $\begin{array}{l}-15.16 \\
(16.18)\end{array}$ & $\begin{array}{l}27.46 \\
(19.90)\end{array}$ \\
\hline No. Banks & 1224 & 1246 & 1236 \\
\hline Bank Level Control & Yes & Yes & Yes \\
\hline Country Level Control & Yes & Yes & Yes \\
\hline Bank Specialization Dummy & Yes & Yes & Yes \\
\hline Crisis Dummy & Yes & Yes & Yes \\
\hline Instruments & Yes & Yes & Yes \\
\hline Hansen Test & Yes & Yes & Yes \\
\hline Under-Ident rk-LM test & Yes & Yes & Yes \\
\hline
\end{tabular}

This table presents the robustness check regression results using Instrumental Variables for an unbalanced panel of European Commercial, Investment,and Realestate banks over the 2001-2013 period to check the impact of network variables on alternative liquidity ratios. We employ IV estimator with bank-specific fixed effect to estimate the following equation:

$\operatorname{LIQ}_{i, t}=\alpha_{0}+\alpha_{1} \operatorname{Netw}(x)_{i, t}+\alpha_{2} B_{i, t}+\alpha_{3} B_{i, t-1}+\alpha_{4} C_{i, t}+\alpha_{5}$ Crisis_subprime $_{t}+\alpha_{6}$ Crisis_sovereign $_{t}+\alpha_{7}$ Investment $_{i}+\alpha_{8}$ Realestate $_{i}+\mu_{\mathrm{i}, \mathrm{t}}+\varepsilon_{i, t}$

Dependent variable $\left(\mathrm{LIQ}_{\mathrm{i}, \mathrm{t}}\right)$ is alternatively NL_DSTF = Net loans to deposits and short-term funds; NL_TA = Net loans to total assets; LA_DSTF $=$ Liquid assets to deposits and short-term funds and NSFR = Net stable funding ratio. Network statistics are our main independent variables including In-Degree, Out-Degree, Clustering Coefficient, Hub, Authority, Betweenness, Closeness and PageRank. Because of high correlation between our network variables, we estimate them by separate equations. $\mathrm{B}_{\mathrm{i}, \mathrm{t}}$ is a vector of bank level control variables including Bank-Size, Z-score, Net interest margin, Return on assets and Cost-income ratio. $\mathrm{B}_{\mathrm{i}, \mathrm{t}-\mathrm{l}}$ is one year lagged value of Equity to total assets. $\mathrm{C}_{\mathrm{i}}$ is a vector of country-level control variables that includes $\mathrm{CB}$ policy Rate, log GDP per capita, inflation, banking sector size and HHI index. Crisis_Subprime and Crisis_Sovereign are dummy variables for Subprime crisis and sovereign crisis respectively. Commercial, Savings, Investment and real estate are bank specialization dummy variables. The Kleibergen-Paap rank LM statistic (Under-Ident rk-LM test) is an underidentification test, to reject the null hypothesis that the equation is underidentified. Hansen Test $\mathrm{F}$ is an overidentification test to reject the null hypothesis that the equation is overidentified. All Dependent and bank-level control variables are winsorized at 5\% - 95\% except network variables. Standard errors are shown in parentheses. *,**,*** indicate significance at the $10 \%, 5 \%$, and $1 \%$ level, respectively. 
Table 10: Instrumental Variable model of network effects on bank's liquidity on the subsamples of highly vs less liquid banks defined on the basis of NSFR and three alternative liquidity ratios

\begin{tabular}{|c|c|c|c|c|c|c|c|c|}
\hline \multirow{2}{*}{$\begin{array}{l}\text { Dependent Variables } \\
\text { Network Variables }\end{array}$} & \multicolumn{2}{|l|}{ NSFR } & \multicolumn{2}{|l|}{ NL-TA } & \multicolumn{2}{|l|}{ NL-DSTF } & \multicolumn{2}{|l|}{ LA-DSTF } \\
\hline & $\begin{array}{l}\text { Highly- } \\
\text { Liquid } \\
\text { (NSFR } \geq 1 \text { ) }\end{array}$ & $\begin{array}{l}\text { Less-Liquid } \\
\text { (Otherwise) }\end{array}$ & $\begin{array}{l}\text { Highly- } \\
\text { Liquid } \\
\text { (NL_TA } \leq 25^{\text {th }} \\
\text { Percentile) }\end{array}$ & $\begin{array}{l}\text { Less-Liquid } \\
\text { (Otherwise) }\end{array}$ & $\begin{array}{l}\text { Highly- } \\
\text { Liquid } \\
\text { (NL_DSTF } \\
\leq 25^{\text {th }} \\
\text { Percentile }\end{array}$ & $\begin{array}{l}\text { Less-Liquid } \\
\text { (Otherwise) }\end{array}$ & $\begin{array}{l}\text { Highly- } \\
\text { Liquid } \\
\text { (LA_DSTF } \\
\geq 75^{\text {th }} \\
\text { Percentile }\end{array}$ & $\begin{array}{l}\text { Less-Liquid } \\
\text { (Otherwise) }\end{array}$ \\
\hline InDegree & $\begin{array}{l}-0.00659 \\
(0.00826)\end{array}$ & $\begin{array}{l}-0.00627^{* *} \\
(0.00316)\end{array}$ & $\begin{array}{l}-0.175 * \\
(0.0949)\end{array}$ & $\begin{array}{l}-0.169 \\
(0.128)\end{array}$ & $\begin{array}{l}-0.403 \\
(0.382)\end{array}$ & $\begin{array}{l}-0.887^{* * *} \\
(0284)\end{array}$ & $0.677 * * *$ & 0.197 \\
\hline OutDegree & $\begin{array}{l}0.0222 \\
(0.0137)\end{array}$ & $\begin{array}{l}-0.00283 \\
(0.00393)\end{array}$ & $\begin{array}{l}0.0542 \\
(0.130)\end{array}$ & $\begin{array}{l}-0.789 * * * \\
(0.167)\end{array}$ & $\begin{array}{l}-0.331 \\
(0.372)\end{array}$ & $\begin{array}{l}-0.853^{* * *} \\
(0.240)\end{array}$ & $\begin{array}{l}0.709 * * \\
(0.351)\end{array}$ & $\begin{array}{l}1.412 * * * \\
(0.263)\end{array}$ \\
\hline ClusteringCoefficient & $\begin{array}{l}0.161 \\
(0.148)\end{array}$ & $\begin{array}{l}0.0346 \\
(0.0855)\end{array}$ & $\begin{array}{l}-4.714 \\
(4.662)\end{array}$ & $\begin{array}{l}-3.655 \\
(3.765)\end{array}$ & $\begin{array}{l}-6.307 \\
(5.932)\end{array}$ & $\begin{array}{l}-11.27 \\
(7.892)\end{array}$ & $\begin{array}{l}9.465 \\
(10.90)\end{array}$ & $\begin{array}{l}4.978 \\
(4.564)\end{array}$ \\
\hline Hub & $\begin{array}{l}1.349 \\
(1.083)\end{array}$ & $\begin{array}{l}-4.633^{* * *} \\
(1.346)\end{array}$ & $\begin{array}{l}104.3 \\
(86.94)\end{array}$ & $\begin{array}{l}-12.86 \\
(14.86)\end{array}$ & $\begin{array}{l}-34.62 \\
(86.70)\end{array}$ & $\begin{array}{l}-110.7^{* * *} \\
(29.90)\end{array}$ & $\begin{array}{l}187.9 * * \\
(95.58)\end{array}$ & $\begin{array}{l}22.95 \\
(21.23)\end{array}$ \\
\hline Authority & $\begin{array}{l}-0.760 \\
(1.192)\end{array}$ & $\begin{array}{l}-2.766^{* * *} \\
(0.517)\end{array}$ & $\begin{array}{l}43.51 \\
(40.60)\end{array}$ & $\begin{array}{l}-2.189 \\
(9.992)\end{array}$ & $\begin{array}{l}-135.7 \\
(94.23)\end{array}$ & $\begin{array}{l}-81.05^{* * *} \\
(23.46)\end{array}$ & $\begin{array}{l}196.7^{* *} \\
(92.79)\end{array}$ & $\begin{array}{l}1.701 \\
(14.97)\end{array}$ \\
\hline BetweennessCentrality & $\begin{array}{l}0.380 \\
(0.352)\end{array}$ & $\begin{array}{l}-0.995^{* * *} \\
(0.276)\end{array}$ & $\begin{array}{l}1.159 \\
(8.790)\end{array}$ & $\begin{array}{l}-26.57^{* * *} \\
(8.337)\end{array}$ & $\begin{array}{l}4.692 \\
(7.815)\end{array}$ & $\begin{array}{l}-61.09 * * * \\
(14.03)\end{array}$ & $\begin{array}{l}-89.88 \\
(102.9)\end{array}$ & $\begin{array}{l}61.08^{*} \\
(35.56)\end{array}$ \\
\hline ClosenessCentrality & $\begin{array}{l}-0.312 \\
(0.464)\end{array}$ & $\begin{array}{l}0.198 \\
(0.501)\end{array}$ & $\begin{array}{l}-11.52 \\
(11.30)\end{array}$ & $\begin{array}{l}-60.86 \\
(45.43)\end{array}$ & $\begin{array}{l}-4.022 \\
(13.89)\end{array}$ & $\begin{array}{l}-371.4 \\
(274.7)\end{array}$ & $\begin{array}{l}-34.58^{*} \\
(19.17)\end{array}$ & $\begin{array}{l}-36.91 \\
(28.54)\end{array}$ \\
\hline PageRank & $\begin{array}{l}-0.873 \\
(0.851)\end{array}$ & $\begin{array}{l}-3.312^{* * *} \\
(1.073)\end{array}$ & $\begin{array}{l}147.7 \\
(123.9)\end{array}$ & $\begin{array}{l}-9.035 \\
(10.64)\end{array}$ & $\begin{array}{l}104.7 \\
(170.5)\end{array}$ & $\begin{array}{l}-103.2^{* * *} \\
(27.29)\end{array}$ & $\begin{array}{l}234.0^{* * *} \\
(83.21)\end{array}$ & $\begin{array}{l}10.13 \\
(15.81)\end{array}$ \\
\hline No. Banks & 596 & 1031 & 418 & 999 & 409 & 994 & 471 & 1040 \\
\hline Bank Level Control & Yes & Yes & Yes & Yes & Yes & Yes & Yes & Yes \\
\hline Country Level Control & Yes & Yes & Yes & Yes & Yes & Yes & Yes & Yes \\
\hline Bank Specialization Dummy & Yes & Yes & Yes & Yes & Yes & Yes & Yes & Yes \\
\hline Crisis Dummy & Yes & Yes & Yes & Yes & Yes & Yes & Yes & Yes \\
\hline Instruments & Yes & Yes & Yes & Yes & Yes & Yes & Yes & Yes \\
\hline Hansen Test & Yes & Yes & Yes & Yes & Yes & Yes & Yes & Yes \\
\hline Under-Ident rk-LM test & Yes & Yes & Yes & Yes & Yes & Yes & Yes & Yes \\
\hline
\end{tabular}

This table presents the robustness check regression results using Instrumental Variables for an unbalanced panel of European Commercial, Investment,and Realestate banks over the 2001-2013 period to check the impact of network variables on NSFR and three alternative liquidity ratios on the subsamples of highly vs less liquid banks. We employ IV estimator with bank-specific fixed effect to estimate the following equation:

LIQ $_{i, t}=\alpha_{0}+\alpha_{1} \operatorname{Netw}(x)_{i, t}+\alpha_{2} B_{i, t}+\alpha_{3} B_{i, t-1}+\alpha_{4} C_{i, t}+\alpha_{5}$ Crisis_subprime $_{t}+\alpha_{6}$ Crisis_sovereign $_{t}+\alpha_{7}$ Investment $_{i}+\alpha_{8}$ Realestate $_{i}+\mu_{\mathrm{i}, \mathrm{t}}+\varepsilon_{i, t}$

Dependent variable $\left(\mathrm{LIQ}_{\mathrm{i}, \mathrm{t}}\right)$ is alternatively NSFR, NL_DSTF = Net loans to deposits and short-term funds; NL_TA = Net loans to total assets; LA_DSTF = Liquid assets to deposits and short-term funds and NSFR = Net stable funding ratio.To define highly liquid banks, we have considered four cases i) banks with NSFR greater than or equal to one (Basel III minimum regulatory requirement), banks with NL_TA less than or equal to $25^{\text {th }}$ percentile, iii) banks with NL_DSTF less than or equal to $25^{\text {th }}$ percentiles and iv) banks with LA_DSTF greater than or equal to $75^{\text {th }}$ percentile.Network statistics are our main independent variables including In-Degree, OutDegree, Clustering Coefficient, Hub, Authority, Betweenness, Closeness and PageRank. Because of high correlation between our network variables, we estimate them by separate equations. $B_{i, t}$ is a vector of bank level control variables including Bank-Size, Z-score, Net interest margin, Return on assets and Cost-income ratio. $B_{i, t-1}$ is one year lagged value of Equity to total assets. $\mathrm{C}_{\mathrm{i}}$ is a vector of country-level control variables that includes CB policy Rate, log GDP per capita, inflation, banking sector size and HHI index. Crisis_Subprime and Crisis_Sovereign are dummy variables for Subprime crisis and sovereign crisis respectively. Commercial, Savings, Investment and real estate are bank specialization dummy variables. The Kleibergen-Paap rank LM statistic (Under-Ident rk-LM test) is an underidentification test, to reject the null hypothesis that the equation is underidentified. Hansen Test F is an overidentification test to reject the null hypothesis that the equation is overidentified. All Dependent and bank-level control variables are winsorized at 5\% - 95\% except network variables. Standard errors are shown in parentheses. *, **, *** indicate significance at the $10 \%, 5 \%$, and $1 \%$ level, respectively. 
Table 11: Instrumental Variable model of network effects on bank's liquidity on the subsamples of highly liquid banks defined on the basis of NSFR during crisis times and normal times.

\begin{tabular}{|c|c|c|c|}
\hline & (1) & (2) & (3) \\
\hline Network variables & Subprime Crisis & Sovereign Crisis & Normal Time \\
\hline \multirow[t]{2}{*}{ InDegree } & -0.0226 & 0.00830 & -0.00583 \\
\hline & $(0.0236)$ & $(0.0280)$ & $(0.0107)$ \\
\hline \multirow[t]{2}{*}{ OutDegree } & -0.00889 & 0.0129 & $0.0269 *$ \\
\hline & $(0.0317)$ & $(0.0382)$ & $(0.0156)$ \\
\hline \multirow[t]{2}{*}{ ClusteringCoefficient } & 0.0421 & -0.113 & 0.140 \\
\hline & $(0.126)$ & $(0.112)$ & $(0.162)$ \\
\hline \multirow[t]{2}{*}{ Hub } & -0.561 & 5.259 & 1.085 \\
\hline & $(2.560)$ & $(4.428)$ & $(0.754)$ \\
\hline \multirow[t]{2}{*}{ Authority } & -0.0304 & 2.740 & -0.225 \\
\hline & $(1.154)$ & $(2.038)$ & $(0.670)$ \\
\hline \multirow[t]{2}{*}{ BetweennessCentrality } & 0.274 & 0.0583 & 0.198 \\
\hline & $(0.265)$ & $(0.524)$ & $(0.266)$ \\
\hline \multirow[t]{2}{*}{ ClosenessCentrality } & -0.00325 & 0.368 & 0.284 \\
\hline & $(0.439)$ & $(0.270)$ & $(0.290)$ \\
\hline \multirow[t]{2}{*}{ PageRank } & -0.461 & 0.0524 & 0.268 \\
\hline & $(0.850)$ & $(1.478)$ & $(0.524)$ \\
\hline No. Banks & 181 & 186 & 523 \\
\hline Bank Level Control & Yes & Yes & Yes \\
\hline Country Level Control & Yes & Yes & Yes \\
\hline Bank Specialization Dummy & No & No & No \\
\hline Crisis Dummy & No & No & No \\
\hline Instruments & Yes & Yes & Yes \\
\hline Hansen Test & Yes & Yes & Yes \\
\hline Under-Ident rk-LM test & Yes & Yes & Yes \\
\hline
\end{tabular}

This table presents the regression results using Instrumental Variables for an unbalanced panel of European Commercial, Investment,and Real-estate banks on different periods to check the impact of network variables on NSFR on the subsamples of highly liquid banks during crisis times and normal times. We employ IV estimator with bank-specific fixed effect to estimate the following equation:

$\operatorname{NSFR}_{i, t}=\alpha_{0}+\alpha_{1} \operatorname{Netw}(x)_{i, t}+\alpha_{2} B_{i, t}+\alpha_{3} B_{i, t-1}+\alpha_{4} C_{i, t}+\alpha_{6}$ Investment $_{i}+\alpha_{7}$ Realestate $_{i}+\mu_{\mathrm{i}, \mathrm{t}}+\varepsilon_{i, t}$

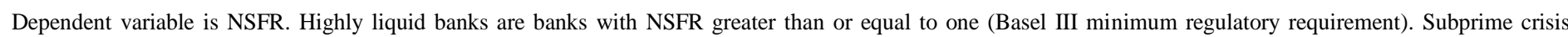

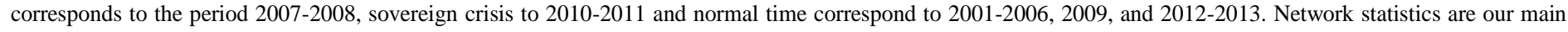

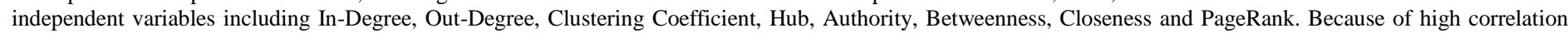

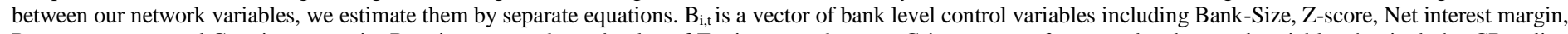

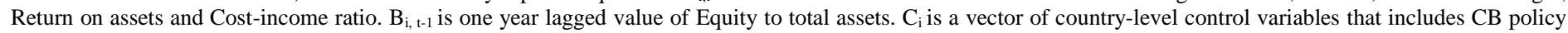

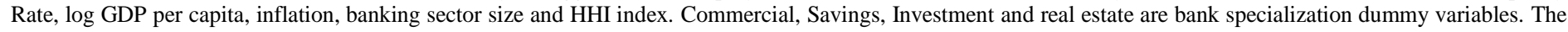

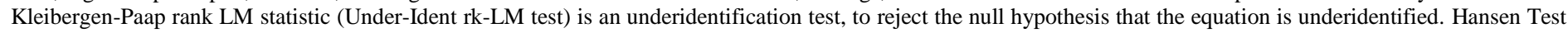

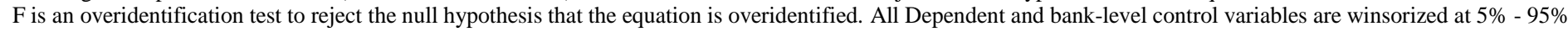
except network variables. Standard errors are shown in parentheses. *, **, *** indicate significance at the $10 \%, 5 \%$, and $1 \%$ level, respectively. 
Table 12: Instrumental Variable model of network effects on bank's liquidity on the subsample of SIFIs on the overall period, during crisis times, normal times and separately for highly liquid SIFIs and less liquid SIFIs.

\begin{tabular}{|c|c|c|c|c|c|}
\hline Variables & $\begin{array}{c}\text { (1) } \\
\text { Overall }\end{array}$ & $\begin{array}{c}(2) \\
N S F R>=1\end{array}$ & $\begin{array}{c}\text { (3) } \\
\text { NSFR<1 }\end{array}$ & $\begin{array}{c}\text { (4) } \\
\text { Crisis-times }\end{array}$ & $\begin{array}{c}\text { (5) } \\
\text { Normal-Times }\end{array}$ \\
\hline \multirow[t]{2}{*}{ InDegree } & -0.00714 & $0.0141 * * *$ & $-0.00932 *$ & 0.0474 & -0.00361 \\
\hline & $(0.00543)$ & $(0.00505)$ & $(0.00484)$ & $(0.0506)$ & $(0.00633)$ \\
\hline \multirow[t]{2}{*}{ OutDegree } & 0.00475 & 0.0211 & $-0.0332 *$ & $0.0382 *$ & -0.00268 \\
\hline & $(0.00613)$ & $(0.0131)$ & $(0.0175)$ & (0.0198) & $(0.00543)$ \\
\hline \multirow[t]{2}{*}{ ClusteringCoefficient } & 1.336 & 0.220 & -1.503 & -0.664 & -0.768 \\
\hline & $(4.367)$ & $(0.325)$ & $(2.523)$ & $(0.958)$ & $(2.395)$ \\
\hline \multirow[t]{2}{*}{ Hub } & -1.263 & $8.065^{*}$ & $-3.007 * * *$ & 34.20 & -2.094 \\
\hline & $(1.118)$ & (4.328) & $(0.928)$ & $(23.04)$ & $(1.632)$ \\
\hline \multirow[t]{2}{*}{ Authority } & $-1.863^{*}$ & $4.866 * * *$ & $-2.943 * * *$ & 24.08 & -1.769 \\
\hline & $(0.962)$ & $(1.818)$ & (0.917) & $(20.52)$ & (1.398) \\
\hline \multirow[t]{2}{*}{ BetweennessCentrality } & -0.446 & $1.418^{* * *}$ & $-1.323 * * *$ & $3.611 * *$ & -0.116 \\
\hline & $(0.299)$ & $(0.310)$ & $(0.342)$ & $(1.678)$ & $(0.367)$ \\
\hline \multirow[t]{2}{*}{ ClosenessCentrality } & -1.267 & $2.319 * *$ & $-3.775 * * *$ & 8.116 & -1.102 \\
\hline & $(0.807)$ & $(1.072)$ & $(1.282)$ & (7.537) & $(0.966)$ \\
\hline \multirow[t]{2}{*}{ PageRank } & $-1.750 * *$ & $2.468 * *$ & $-2.486 * * *$ & $4.958 * *$ & -1.267 \\
\hline & $(0.712)$ & $(0.996)$ & $(0.691)$ & $(2.190)$ & $(0.810)$ \\
\hline No. Banks & 37 & 17 & 33 & 27 & 36 \\
\hline Bank Level Control & Yes & Yes & Yes & Yes & Yes \\
\hline Country Level Control & Yes & Yes & Yes & Yes & Yes \\
\hline Bank Specialization Dummy & No & No & No & No & No \\
\hline Crisis Dummy & No & No & No & No & No \\
\hline Instruments & Yes & Yes & Yes & Yes & Yes \\
\hline Hansen Test & Yes & Yes & Yes & Yes & Yes \\
\hline Under-Ident rk-LM test & Yes & Yes & Yes & Yes & Yes \\
\hline
\end{tabular}

This table presents the regression results using Instrumental Variables for an unbalanced panel of European SIFIsto check the impact of network variables on NSFR on the subsamples of SIFIs on the overall period, during crisis times, normal times and separately for highly liquid SIFIs and less liquid SIFIs. We employ IV estimator with bank-specific fixed effect to estimate the following equation:

$\operatorname{NSFR}_{i, t}=\alpha_{0}+\alpha_{1} \operatorname{Netw}(x)_{i, t}+\alpha_{2} B_{i, t}+\alpha_{3} B_{i, t-1}+\alpha_{4} C_{i, t}+\mu_{\mathrm{i}, \mathrm{t}}+\varepsilon_{i, t}$

Dependent variable is NSFR. Highly liquid banks are banks with NSFR greater than or equal to one (Basel III minimum regulatory requirement). The overall period corresponds to 2001-2013, subprime crisis corresponds to the period 2007-2008, sovereign crisis to 2010-2011 and normal time correspond to 2001-2006, 2009, and 2012-2013.Network statistics are our main independent variables including In-Degree, Out-Degree, Clustering Coefficient, Hub, Authority, Betweenness, Closeness and PageRank. Because of high correlation between our network variables, we estimate them by separate equations. $\mathrm{B}_{\mathrm{i}, \mathrm{t}}$ is a vector of bank level control variables including Bank-Size, Z-score, Net interest margin, Return on assets and Cost-income ratio. $\mathrm{B}_{\mathrm{i}, \mathrm{t}-1}$ is one year lagged value of Equity to total assets. $\mathrm{C}_{\mathrm{i}}$ is a vector of country-level control variables that includes CB policy Rate, log GDP per capita, inflation, banking sector size and HHI index. The Kleibergen-Paap rank LM statistic (Under-Ident rk-LM test) is an underidentification test, to reject the null hypothesis that the equation is underidentified. Hansen Test $\mathrm{F}$ is an overidentification test to reject the null hypothesis that the equation is overidentified. All Dependent and bank-level control variables are winsorized at 5\% - 95\% except network variables. Standard errors are shown in parentheses. *,**,*** indicate significance at the $10 \%, 5 \%$, and $1 \%$ level, respectively. 
Table 13: Fixed Effect model of NSFR determinants and the contribution of network variables on the structural liquidity model

\begin{tabular}{|c|c|c|c|c|c|c|c|c|c|c|c|c|}
\hline & $(1)$ & $(2)$ & (3) & (4) & (5) & $(6)$ & (7) & (8) & (9) & $(10)$ & (11) & $(12)$ \\
\hline & NSFR & NSFR & NSFR & NSFR & NSFR & NSFR & NSFR & NSFR & NSFR & NSFR & NSFR & NSFR \\
\hline \multirow[t]{2}{*}{ zscore } & $-0.000125^{*}$ & -0.000111 & -0.000110 & $-0.000123^{*}$ & -0.000117 & $-0.000123^{*}$ & $-0.000123^{*}$ & -0.000120 & -0.000122 & $-0.000123^{*}$ & $-0.000124 *$ & -0.000121 \\
\hline & $(0.0000756)$ & $(0.0000749)$ & $(0.0000748)$ & $(0.0000746)$ & $(0.0000742)$ & $(0.0000745)$ & $(0.0000746)$ & $(0.0000744)$ & $(0.0000744)$ & $(0.0000745)$ & $(0.0000745)$ & $(0.0000743)$ \\
\hline \multirow[t]{2}{*}{ NIM } & -0.00711 & -0.00838 & -0.00820 & -0.00849 & -0.00954 & -0.00800 & -0.00826 & -0.00905 & -0.00916 & -0.00854 & -0.00845 & -0.00943 \\
\hline & $(0.0102)$ & (0.0109) & (0.0109) & (0.0109) & (0.0109) & $(0.0108)$ & (0.0109) & $(0.0109)$ & $(0.0108)$ & (0.0109) & $(0.0109)$ & (0.0109) \\
\hline \multirow[t]{2}{*}{ ROA } & $0.0389 * * *$ & $0.0370 * * *$ & $0.0364 * * *$ & $0.0343 * * *$ & $0.0338 * * *$ & $0.0342^{* * *}$ & $0.0345^{* * *}$ & $0.0340 * * *$ & $0.0338 * * *$ & $0.0344 * * *$ & $0.0344 * * *$ & $0.0341 * * *$ \\
\hline & $(0.0105)$ & $(0.0109)$ & (0.0109) & $(0.0110)$ & $(0.0107)$ & $(0.0110)$ & $(0.0110)$ & $(0.0109)$ & $(0.0109)$ & $(0.0110)$ & $(0.0110)$ & (0.0109) \\
\hline \multirow[t]{2}{*}{ Cost_Inc } & -0.000356 & -0.000321 & -0.000373 & -0.000409 & -0.000492 & -0.000406 & -0.000406 & -0.000454 & -0.000481 & -0.000411 & -0.000407 & -0.000454 \\
\hline & $(0.000626)$ & $(0.000633)$ & $(0.000633)$ & (0.000631) & $(0.000623)$ & $(0.000632)$ & $(0.000631)$ & $(0.000629)$ & $(0.000629)$ & $(0.000631)$ & $(0.000632)$ & $(0.000629)$ \\
\hline \multirow[t]{2}{*}{ L.Equity/TA } & $0.00769 * * *$ & $0.00860 * * *$ & $0.00868^{* * *}$ & $0.00877^{* * *}$ & $0.00868 * * *$ & $0.00878^{* * *}$ & $0.00876^{* * *}$ & $0.00875^{* * *}$ & $0.00872^{* * *}$ & $0.00877^{* * *}$ & $0.00877^{* * *}$ & $0.00873^{* * *}$ \\
\hline & $(0.00218)$ & $(0.00217)$ & $(0.00216)$ & $(0.00216)$ & $(0.00215)$ & $(0.00216)$ & $(0.00216)$ & $(0.00216)$ & $(0.00215)$ & $(0.00216)$ & $(0.00216)$ & $(0.00216)$ \\
\hline \multirow[t]{2}{*}{ CB_Policyrate } & & $0.0184^{* * *}$ & $0.0181^{* * *}$ & $0.0207^{* * *}$ & $0.0212^{* * *}$ & $0.0205^{* * *}$ & $0.0208^{* * *}$ & $0.0203^{* * *}$ & $0.0203^{* * *}$ & $0.0207^{* * *}$ & $0.0207^{* * *}$ & $0.0205^{* * *}$ \\
\hline & & $(0.00560)$ & $(0.00561)$ & $(0.00618)$ & $(0.00615)$ & $(0.00618)$ & $(0.00618)$ & $(0.00616)$ & $(0.00616)$ & $(0.00619)$ & $(0.00618)$ & $(0.00616)$ \\
\hline \multirow[t]{2}{*}{ LogGDPperCap } & & -0.190 & -0.184 & -0.0428 & -0.0511 & -0.0399 & -0.0436 & -0.0835 & -0.0874 & -0.0445 & -0.0419 & -0.0730 \\
\hline & & $(0.130)$ & $(0.130)$ & (0.139) & (0.139) & $(0.139)$ & $(0.139)$ & $(0.140)$ & $(0.140)$ & $(0.138)$ & $(0.139)$ & $(0.139)$ \\
\hline \multirow[t]{2}{*}{ Inflation } & & $-0.00729 *$ & $-0.00733^{*}$ & -0.00433 & -0.00420 & -0.00437 & -0.00432 & -0.00376 & -0.00377 & -0.00434 & -0.00438 & -0.00394 \\
\hline & & $(0.00395)$ & $(0.00396)$ & $(0.00398)$ & $(0.00395)$ & $(0.00398)$ & $(0.00397)$ & $(0.00398)$ & $(0.00396)$ & $(0.00398)$ & $(0.00398)$ & $(0.00395)$ \\
\hline \multirow[t]{2}{*}{ country_TA_GDP } & & $0.446 * * *$ & $0.449 * * *$ & $0.518 * * *$ & $0.511^{* * *}$ & $0.520 * * *$ & $0.518^{* * *}$ & $0.513^{* * *}$ & $0.511^{* * *}$ & $0.518^{* * *}$ & $0.519 * * *$ & $0.512 * * *$ \\
\hline & & $(0.114)$ & $(0.113)$ & $(0.116)$ & $(0.115)$ & $(0.116)$ & $(0.116)$ & $(0.116)$ & $(0.115)$ & $(0.116)$ & $(0.116)$ & $(0.115)$ \\
\hline \multirow[t]{2}{*}{ hhi_TA } & & -0.300 & -0.302 & -0.263 & -0.263 & -0.263 & -0.260 & -0.205 & -0.200 & -0.263 & -0.268 & -0.221 \\
\hline & & $(0.228)$ & $(0.228)$ & $(0.230)$ & $(0.230)$ & $(0.230)$ & $(0.231)$ & $(0.232)$ & $(0.231)$ & $(0.230)$ & $(0.230)$ & $(0.231)$ \\
\hline \multirow[t]{2}{*}{ investment } & & & $0.322^{* *}$ & $0.322^{* *}$ & $0.318^{* *}$ & $0.320 * *$ & $0.319^{* *}$ & $0.343^{* * *}$ & $0.353^{* * *}$ & $0.322^{* *}$ & $0.322^{* *}$ & $0.342^{* * *}$ \\
\hline & & & $(0.133)$ & $(0.136)$ & $(0.129)$ & $(0.133)$ & $(0.136)$ & $(0.0793)$ & $(0.0624)$ & $(0.135)$ & $(0.136)$ & $(0.0869)$ \\
\hline \multirow[t]{2}{*}{ realestate } & & & $-0.250 * * *$ & $-0.241 * * *$ & $-0.243^{* * *}$ & $-0.240 * * *$ & $-0.244^{* * *}$ & $-0.242 * * *$ & $-0.242^{* * *}$ & $-0.241 * * *$ & $-0.240 * * *$ & $-0.241 * * *$ \\
\hline & & & $(0.0161)$ & $(0.0162)$ & $(0.0163)$ & $(0.0163)$ & $(0.0165)$ & $(0.0162)$ & $(0.0162)$ & $(0.0163)$ & $(0.0164)$ & $(0.0162)$ \\
\hline \multirow[t]{2}{*}{ crisis_subprime } & & & & $-0.0473^{* * *}$ & $-0.0486^{* * *}$ & $-0.0470 * * *$ & $-0.0477^{* * *}$ & $-0.0452^{* * *}$ & $-0.0452^{* * *}$ & $-0.0472 * * *$ & $-0.0472^{* * *}$ & $-0.0462^{* * *}$ \\
\hline & & & & $(0.0157)$ & $(0.0157)$ & $(0.0157)$ & $(0.0157)$ & $(0.0157)$ & $(0.0157)$ & $(0.0158)$ & $(0.0157)$ & $(0.0157)$ \\
\hline \multirow[t]{2}{*}{ crisis_sovereign } & & & & $-0.0520 * * *$ & $-0.0527^{* * *}$ & $-0.0520 * * *$ & $-0.0524 * * *$ & $-0.0524 * * *$ & $-0.0523 * * *$ & $-0.0520 * * *$ & $-0.0517^{* * *}$ & $-0.0525 * * *$ \\
\hline & & & & $(0.0105)$ & $(0.0105)$ & (0.0105) & $(0.0105)$ & $(0.0105)$ & $(0.0105)$ & $(0.0105)$ & $(0.0105)$ & $(0.0106)$ \\
\hline InDegree & & & & & $\begin{array}{l}-0.0110 * * * \\
(0.00367)\end{array}$ & & & & & & & \\
\hline \multirow[t]{2}{*}{ OutDegree } & & & & & & 0.00475 & & & & & & \\
\hline & & & & & & $(0.00387)$ & & & & & & \\
\hline \multirow[t]{2}{*}{ ClusteringCoefficient } & & & & & & & $-0.0244^{*}$ & & & & & \\
\hline & & & & & & & $(0.0148)$ & & & & & \\
\hline \multirow[t]{2}{*}{ Hub } & & & & & & & & $-1.085^{* * *}$ & & & & \\
\hline & & & & & & & & $(0.245)$ & & & & \\
\hline \multirow[t]{2}{*}{ Authority } & & & & & & & & & $-1.167 * * *$ & & & \\
\hline & & & & & & & & & $(0.231)$ & & & \\
\hline \multirow[t]{2}{*}{ BetweennessCentrality } & & & & & & & & & & -0.00993 & & \\
\hline & & & & & & & & & & $(0.0518)$ & & \\
\hline ClosenessCentrality & & & & & & & & & & & 0.0196 & \\
\hline & & & & & & & & & & & $(0.0369)$ & \\
\hline PageRank & & & & & & & & & & & & $-0.746^{* * *}$ \\
\hline & & & & & & & & & & & & $(0.129)$ \\
\hline
\end{tabular}




\begin{tabular}{|c|c|c|c|c|c|c|c|c|c|c|c|c|}
\hline _cons & $\begin{array}{l}0.730 * * * \\
(0.0544)\end{array}$ & $\begin{array}{l}5.792 \\
(3.538)\end{array}$ & $\begin{array}{l}5.631 \\
(3.540)\end{array}$ & $\begin{array}{l}1.771 \\
(3.807)\end{array}$ & $\begin{array}{l}2.029 \\
(3.800)\end{array}$ & $\begin{array}{l}1.682 \\
(3.794)\end{array}$ & $\begin{array}{l}1.796 \\
(3.809)\end{array}$ & $\begin{array}{l}2.901 \\
(3.834)\end{array}$ & $\begin{array}{l}3.012 \\
(3.818)\end{array}$ & $\begin{array}{l}1.817 \\
(3.779)\end{array}$ & $\begin{array}{l}1.742 \\
(3.799)\end{array}$ & $\begin{array}{l}2.609 \\
(3.807)\end{array}$ \\
\hline $\mathbf{N}$ & 11424 & 11333 & 11333 & 11333 & 11333 & 11333 & 11333 & 11333 & 11333 & 11333 & 11333 & 11317 \\
\hline \multicolumn{13}{|l|}{ N_g } \\
\hline r2 & 0.704 & 0.709 & 0.709 & 0.710 & 0.711 & 0.710 & 0.710 & 0.711 & 0.711 & 0.710 & 0.710 & 0.711 \\
\hline Wald-Test P-value & & & & & 0.0027 & 0.2198 & 0.0990 & 0.0000 & 0.0000 & 0.8480 & 0.5954 & 0.0000 \\
\hline
\end{tabular}

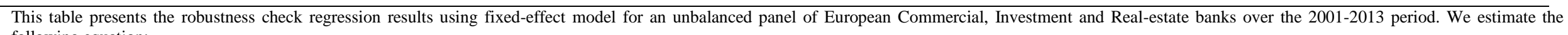
following equation:

$\operatorname{NSFR}_{i, t}=\alpha_{0}+\alpha_{1} \operatorname{Netw}(x)_{i, t}+\alpha_{2} B_{i, t}+\alpha_{3} B_{i, t-1}+\alpha_{4} C_{i, t}+\alpha_{5}$ Crisis_subprime $_{t}+\alpha_{6}$ Crisis_sovereign $_{t}+\alpha_{7}$ Investment $_{i}+\alpha_{8}$ Realestate $_{i}+\mu_{\mathrm{i}, t}+\varepsilon_{i, t}$

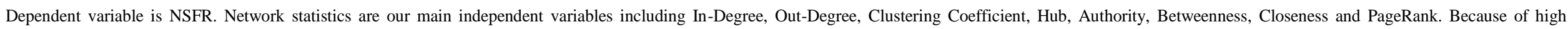

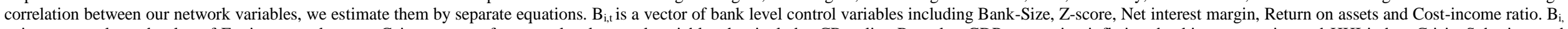

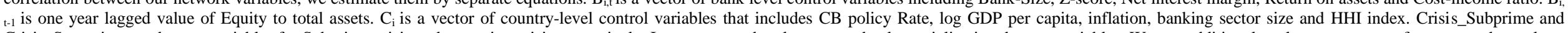

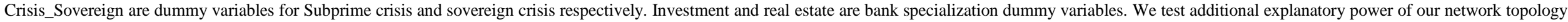

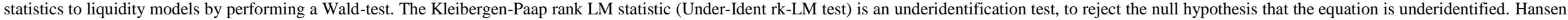

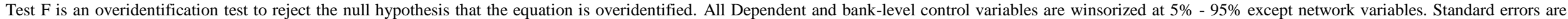
shown in parentheses. $* * *, * * *$ indicate significance at the $10 \%, 5 \%$, and $1 \%$ level, respectively. 


\section{Appendix}

\section{Minimum Density}

Minimum density (MD) is an efficient and streamline alternative to the maximum entropy method, which lessens the total number of links between nodes, consistent with total lending and borrowing observed for each bank, with the assumption that keeping a high degree of linkage is costly for banks. MD is introduced by Anand et al., 2015.

The constrained optimization problem for the MD approach is:

$\min _{Z} c \sum_{i}^{N} \sum_{j}^{N} 1\left[Z_{i j}>0\right] \quad$ s.t

$\sum_{j=1}^{N} Z_{i j}=L T B_{i} \quad \forall i=1,2, \ldots, N$

$\sum_{i=1}^{N} Z_{i j}=D F B_{j} \quad \forall j=1,2, \ldots, N$

$Z_{i j} \geq 0$

Where $\mathrm{Z}$ is a matrix of interbank exposure, $\mathrm{c}$ is linkage establishment fixed cost and integer function, and 1 equals one if and only if bank $\mathrm{i}$ lends to bank $\mathrm{j}$. In this method, the bank capacity is constrained by the aggregate amounts of its interbank loans (LTB = Loans to banks) and deposits (DFB = Deposits from Banks) which are considered as marginals and the fixed cost "c" of establishing credit relationships. In the next step, the link-generating algorithm presents which one of its specific features is imposing penalty for deviations from marginal:

$L T B_{-} D_{i} \equiv\left(L T B_{i}-\sum_{j} Z_{i j}\right)$

$D F B_{D_{i}} \equiv\left(D F B_{i}-\sum_{j} Z_{j i}\right)$ 
Where $L T B_{-} D_{i}$ and $D F B_{-} D_{i}$ measure bank i current deficit from marginals (i.e. how much its bilateral borrowing falls short of the total amount it needs to raise). Hence, by adding this criterion to the objective function, the model maximizes the value of sparse matrix $\mathrm{Z}$ that minimizes marginal deviations:

$\mathrm{V}(\mathrm{Z})=-c \sum_{i=1}^{N} \sum_{j=1}^{N} 1\left[Z_{i j}>0\right]-\sum_{i=1}^{N}\left(\propto_{i} L T B_{i}^{2}+\delta_{i} D F B_{i}^{2}\right)$

To capture disassortative ${ }^{8}$ characteristics of interbank network, a set of probabilities $\mathrm{Q}$ is defined:

$Q_{i j} \propto \max \left\{\frac{L T B_{-D_{i}}}{D F B_{-D_{j}}}, \frac{D F B_{-D_{j}}}{L T B_{-D_{i}}}\right\}$

According to the probability $Q$, lending probability of $i$ to $j$ would increase if either $i$ is a large lender to a small borrower $\mathrm{j}$, or $\mathrm{i}$ is a small lender to a large borrower $\mathrm{j}$.

And finally, the network will be produced by the maximization function:

$\sum_{Z} P(Z) V(Z)+\theta R(P \| Q)$

Where $\mathrm{P}(\mathrm{Z})$ is the probability distribution over all possible network configuration, $\mathrm{R}$ is the relative entropy function and $\theta$ is a scaling parameter that determines the weight on a new solution with common feature with prior matrix $\mathrm{Q}^{9}$.

${ }^{8}$ Disassortative features of interbank markets are defined by Anand, Craig, \& von Peter (2015) as a tendency of small banks to setup borrowing-lending relationships with larger banks that are well placed to satisfy those needs. In this model, bank size is measured based on the current deficit and surplus from marginals.

${ }^{9}$ This algorithm has been constructed and run with a Matlab program. The heuristic process that executes this method is fully described in Anand et al. (2015). 
Table A1: Descriptive Statistics on Summary Accounting Information of the raw sample of banks and the 1328 banks of our sample on the period 2001-2013.

\begin{tabular}{|c|c|c|c|c|c|c|c|c|c|c|}
\hline & \multicolumn{5}{|c|}{ Full sample available in Bankscope } & \multicolumn{5}{|c|}{ Our sample } \\
\hline Variables & Mean & Std. Dev. & Min & Median & Max & Mean & Std. Dev. & Min & Median & Max \\
\hline Total Assets th\$ & 8861494 & $1.94 \mathrm{E}+07$ & 41733.3 & 1152300 & $8.02 E+07$ & $1.03 \mathrm{E}+07$ & $2.07 \mathrm{E}+07$ & 41733.3 & 1580950 & $8.02 \mathrm{E}+07$ \\
\hline $\begin{array}{c}\text { Net loans/Total } \\
\text { Assets (\%) }\end{array}$ & 50.76 & 27.57 & 2.48 & 55.65 & 92.47 & 51.89 & 26.94 & 2.48 & 57.19 & 92.47 \\
\hline $\begin{array}{l}\text { Equity/Net Loans } \\
\text { (\%) }\end{array}$ & 33.98 & 45.96 & 4.11 & 15.52 & 187.02 & 31.03 & 42.51 & 4.11 & 14.79 & 187.02 \\
\hline $\begin{array}{l}\text { Net Loans/Deposits } \\
\text { and short-term } \\
\text { funds (\%) }\end{array}$ & 72.47 & 44.22 & 5.13 & 72.73 & 180.09 & 73.40 & 43.53 & 5.13 & 74.49 & 180.09 \\
\hline Net interest margin & 2.39 & 1.80 & 0.13 & 1.98 & 7.02 & 2.28 & 1.6 & 0.13 & 1.95 & 7.02 \\
\hline ROA & 0.67 & 1.17 & -1.94 & 0.50 & 3.59 & 0.65 & 1.06 & -1.94 & 0.50 & 3.59 \\
\hline $\begin{array}{l}\text { Equity to Total } \\
\text { assets }\end{array}$ & 12.58 & 12.79 & 2.13 & 8.03 & 53.33 & 11.04 & 10.71 & 2.13 & 7.67 & 53.33 \\
\hline
\end{tabular}


Table A2: Correlation matrix of explanatory and control variables

\begin{tabular}{|c|c|c|c|c|c|c|c|c|c|c|}
\hline & InDegree & OutDegree & Closeness & Betweenness & Authority & Hub & ClusteringCo & PageRank & Bank-Size & \\
\hline InDegree & 1 & & & & & & & & & \\
\hline OutDegree & 0.7815 & 1 & & & & & & & & \\
\hline Closeness & 0.2049 & 0.2736 & 1 & & & & & & & \\
\hline Betweenness & 0.5636 & 0.5639 & 0.4744 & 1 & & & & & & \\
\hline Authority & 0.4383 & 0.3107 & 0.5021 & 0.6762 & 1 & & & & & \\
\hline$H u b$ & 0.409 & 0.3135 & 0.5833 & 0.6786 & 0.9526 & 1 & & & & \\
\hline ClusteringCo & -0.1117 & -0.126 & 0.0464 & -0.1307 & -0.0375 & -0.0331 & 1 & & & \\
\hline PageRank & 0.4773 & 0.3636 & 0.5234 & 0.7334 & 0.9243 & 0.9018 & -0.0641 & 1 & & \\
\hline Bank-Size & 0.4261 & 0.4197 & 0.1575 & 0.3783 & 0.2616 & 0.2476 & -0.1061 & 0.2899 & 1 & \\
\hline Z-Score & -0.0366 & -0.0448 & -0.0688 & -0.0701 & -0.1173 & -0.1228 & 0.0153 & -0.0991 & -0.0184 & \\
\hline NIM & -0.115 & -0.1259 & 0.0543 & -0.0405 & 0.0825 & 0.097 & 0.0336 & 0.0512 & -0.3134 & \\
\hline$R O A$ & -0.0533 & -0.0461 & 0.0279 & 0.0116 & 0.0397 & 0.0371 & 0.0253 & 0.03 & -0.1415 & \\
\hline Cost_Inc & -0.062 & -0.0346 & -0.0615 & -0.1016 & -0.0994 & -0.093 & 0.006 & -0.0992 & -0.1901 & \\
\hline I.Eq_TA & -0.1577 & -0.1492 & -0.0677 & -0.136 & -0.0974 & -0.0878 & 0.0048 & -0.1031 & -0.5012 & \\
\hline hhi_TA & 0.0036 & 0.0009 & 0.3211 & 0.1179 & 0.3667 & 0.3895 & 0.1007 & 0.3071 & 0.0269 & \\
\hline CB_Policyrate & 0.003 & 0.002 & 0.0405 & 0.003 & 0.0132 & 0.012 & 0.0356 & 0.0125 & -0.0489 & \\
\hline LogGDPperCap & 0.0042 & 0.0043 & -0.3436 & -0.187 & -0.3937 & -0.4215 & -0.0385 & -0.3262 & 0.0194 & \\
\hline Inflation & -0.0117 & -0.0125 & 0.1571 & 0.084 & 0.2205 & 0.2348 & -0.0154 & 0.1866 & -0.0741 & \\
\hline \multirow[t]{2}{*}{ Sector-Size } & 0.0073 & 0.011 & -0.0824 & 0.0059 & -0.1528 & -0.1624 & -0.0244 & -0.1282 & 0.1085 & \\
\hline & Z-Score & NIM & $\mathrm{ROA}$ & Cost_Inc & I.Eq_TA & hhi_TA & CB_Policyrate & LogGDPperCap & Inflation & Sector-Size \\
\hline Z-Score & 1 & & & & & & & & & \\
\hline NIM & -0.0743 & 1 & & & & & & & & \\
\hline$R O A$ & 0.0122 & 0.2677 & 1 & & & & & & & \\
\hline Cost_Inc & -0.131 & -0.0147 & -0.4465 & 1 & & & & & & \\
\hline I.Eq_TA & 0.0341 & 0.2631 & 0.3015 & 0.0023 & 1 & & & & & \\
\hline hhi_TA & -0.0371 & 0.0666 & 0.0497 & -0.0253 & 0.0164 & 1 & & & & \\
\hline CB_Policyrate & 0.0602 & 0.0948 & 0.1749 & -0.0509 & -0.0062 & 0.0131 & 1 & & & \\
\hline LogḠDPperCap & 0.1385 & 0.0182 & -0.0257 & 0.0763 & 0.0442 & -0.129 & -0.0096 & 1 & & \\
\hline Inflation & -0.0799 & 0.2442 & 0.072 & 0.0284 & 0.0431 & 0.0831 & 0.1233 & -0.2007 & 1 & \\
\hline Sector-Size & -0.0175 & -0.312 & -0.0443 & -0.0748 & -0.0912 & -0.4325 & 0.0065 & -0.37 & -0.0684 & 1 \\
\hline
\end{tabular}

This table presents the correlation matrix for network variables, bank level and country level control variables. As the network variables are highly correlated, we introduce them in the equation one by one. All dependent and bank-level control variables are winsorized at $5 \%-95 \%$ except network variables. 
Table A3: Descriptive Statistics on the subsamples of banks with their NSFR ratio more than 1 vs less than 1.

\begin{tabular}{|c|c|c|c|c|c|c|c|c|c|c|}
\hline \multirow[b]{2}{*}{ Variables } & \multicolumn{5}{|c|}{ Subsample of banks with NSFR $\geq 1$} & \multicolumn{5}{|c|}{ Subsample of banks with NSFR $<1$} \\
\hline & Mean & Sd. & Min & Median & Max & Mean & Sd. & Min & Median & Max \\
\hline NSFR & 1.531 & 0.492 & 1.000 & 1.336 & 2.449 & 0.468 & 0.321 & 0.046 & 0.442 & .9999 \\
\hline NL_DSTF & 54.080 & 41.916 & 5.137 & 47.936 & 180.099 & 81.285 & 41.688 & 5.137 & 81.949 & 180.099 \\
\hline zscore & 60.841 & 69.816 & 3.284 & 35.878 & 311.580 & 73.231 & 84.289 & 3.284 & 39.816 & 311.580 \\
\hline NIM & 2.191 & 1.667 & 0.132 & 1.834 & 7.026 & 2.332 & 1.636 & 0.132 & 1.989 & 7.026 \\
\hline ROA & 0.859 & 1.158 & -1.942 & 0.667 & 3.597 & 0.564 & 1.002 & -1.942 & 0.447 & 3.597 \\
\hline Cost_Inc & 64.089 & 24.157 & 21.563 & 63.263 & 118.519 & 63.370 & 21.833 & 21.563 & 62.860 & 118.519 \\
\hline Eq_TA & 13.313 & 13.307 & 2.050 & 8.560 & 53.252 & 10.031 & 9.173 & 2.050 & 7.310 & 53.252 \\
\hline InDegree & 1.414 & 2.709 & 0.000 & 1.000 & 55.000 & 2.090 & 3.989 & 0.000 & 1.000 & 61.000 \\
\hline OutDegree & 1.914 & 3.358 & 0.000 & 1.000 & 53.000 & 1.841 & 3.108 & 0.000 & 1.000 & 49.000 \\
\hline ClusteringCo & 0.182 & 0.297 & 0.000 & 0.000 & 1.000 & 0.188 & 0.295 & 0.000 & 0.000 & 1.000 \\
\hline Hub & 0.026 & 0.038 & 0.000 & 0.011 & 0.385 & 0.026 & 0.039 & 0.000 & 0.010 & 0.360 \\
\hline Authority & 0.025 & 0.040 & 0.000 & 0.010 & 0.500 & 0.026 & 0.043 & 0.000 & 0.009 & 0.471 \\
\hline Betweenness & 0.049 & 0.135 & 0.000 & 0.002 & 1.000 & 0.051 & 0.131 & 0.000 & 0.003 & 1.000 \\
\hline Closeness & 0.331 & 0.143 & 0.000 & 0.297 & 1.000 & 0.309 & 0.125 & 0.000 & 0.286 & 1.000 \\
\hline PageRank & 0.024 & 0.046 & 0.000 & 0.008 & 0.475 & 0.027 & 0.053 & 0.000 & 0.008 & 0.471 \\
\hline
\end{tabular}

This table presents the descriptive statistics for banks with NSFR $\geq 1$ and banks with NSFR<1 on the period 2001-2013; NSFR= Net Stable Funding Ratio; NL_DSTF= Net Loans to Deposits and Short-term funds; Network variables= InDegree, OutDegree, ClusteringCo, Hub, Authority, Betweenness, Closeness, PageRank; NIM= Net Interest Margin; ROA= Return on Assets; Cost_Inc= Cost-income ratio and Eq_TA= Equity to total assets.All dependent and bank-level control variables are winsorized at $5 \%-95 \%$ except network variables. 
Table A4: Distribution of banks with NSFR $\geq 1$ in 28 European Countries, during Subprime Crisis, Sovereign Crisis and on the overall period

\begin{tabular}{|c|c|c|c|c|c|c|c|}
\hline \multirow[b]{2}{*}{ CountryName } & \multicolumn{3}{|l|}{ All Periods } & \multicolumn{2}{|l|}{ Subprime Crisis } & \multicolumn{2}{|l|}{ Sovereign Crisis } \\
\hline & $\begin{array}{l}\text { (1) } \\
\text { Number of banks } \\
\text { in our sample }\end{array}$ & $\begin{array}{l}\text { (2) } \\
\text { Average Number } \\
\text { of banks with } \\
\text { NSFR } \geq 1\end{array}$ & $\begin{array}{l}\text { (3) } \\
\text { Percentage of total assets of the banking } \\
\text { sector in banks with NSFR } \geq 1\end{array}$ & $\begin{array}{l}\text { (4) } \\
\text { Number of banks } \\
\text { with NSFR } \geq 1\end{array}$ & $\begin{array}{l}\text { (5) } \\
\text { Percentage of total } \\
\text { assets of the banking } \\
\text { sector in banks with } \\
\text { NSFR } \geq 1\end{array}$ & $\begin{array}{l}6) \\
\text { Number of banks } \\
\text { with NSFR } \geq 100 \%\end{array}$ & $\begin{array}{l}\text { (7) } \\
\text { Percentage of total } \\
\text { assets of the banking } \\
\text { sector in banks with } \\
\text { NSFR } \geq 1\end{array}$ \\
\hline AUSTRIA & 75 & 22 & 25.82 & 42 & 25.46 & 10 & 4.56 \\
\hline BELGIUM & 22 & 3 & 11.42 & 5 & 17.51 & 2 & 0.63 \\
\hline BULGARIA & 17 & 7 & 60.35 & 7 & 66.06 & 6 & 29.52 \\
\hline CROATIA & 27 & 10 & 55.47 & 13 & 91.12 & 9 & 16.83 \\
\hline CYPRUS & 5 & 2 & 54.92 & 3 & 78.33 & 0 & 0.00 \\
\hline CZECH REPUBLIC & 18 & 7 & 84.26 & 5 & 45.50 & 6 & 80.58 \\
\hline DENMARK & 38 & 7 & 44.26 & 6 & 27.77 & 7 & 40.19 \\
\hline ESTONIA & 6 & 2 & 40.13 & 1 & 0.86 & 1 & 1.37 \\
\hline FINLAND & 10 & 2 & 15.50 & 3 & 15.18 & 1 & 0.18 \\
\hline FRANCE & 122 & 21 & 27.63 & 24 & 48.70 & 18 & 9.43 \\
\hline GERMANY & 153 & 13 & 30.26 & 14 & 24.33 & 15 & 45.38 \\
\hline GREECE & 4 & 1 & 31.40 & 4 & 29.25 & 1 & 1.15 \\
\hline HUNGARY & 21 & 3 & 24.82 & 4 & 3.20 & 3 & 1.20 \\
\hline IRELAND & 13 & 3 & 20.44 & 8 & 38.97 & 3 & 9.21 \\
\hline ITALY & 77 & 28 & 32.87 & 38 & 28.62 & 26 & 34.58 \\
\hline LATVIA & 15 & 6 & 45.23 & 7 & 61.15 & 7 & 28.38 \\
\hline LITHUANIA & 9 & 2 & 38.57 & 1 & 10.45 & 1 & 16.14 \\
\hline LUXEMBOURG & 48 & 28 & 51.94 & 38 & 66.39 & 27 & 40.27 \\
\hline MALTA & 8 & 4 & 87.61 & 4 & 58.68 & 6 & 85.06 \\
\hline NETHERLANDS & 23 & 5 & 16.17 & 7 & 4.34 & 5 & 1.40 \\
\hline POLAND & 28 & 7 & 43.88 & 7 & 62.13 & 6 & 40.58 \\
\hline PORTUGAL & 21 & 4 & 6.55 & 5 & 3.73 & 5 & 2.09 \\
\hline ROMANIA & 17 & 6 & 58.58 & 9 & 42.35 & 4 & 6.52 \\
\hline SLOVAKIA & 11 & 5 & 79.72 & 7 & 78.01 & 4 & 78.24 \\
\hline SLOVENIA & 12 & 5 & 68.68 & 4 & 63.53 & 1 & 1.71 \\
\hline SPAIN & 24 & 12 & 2.40 & 11 & 2.58 & 7 & 1.29 \\
\hline SWEDEN & 26 & 3 & 39.74 & 4 & 40.55 & 2 & 33.99 \\
\hline UNITED KINGDOM & 151 & 50 & 27.43 & 54 & 50.55 & 48 & 15.16 \\
\hline Total & 1001 & 268 & 37.20 & 335 & 42.69 & 231 & 26.59 \\
\hline
\end{tabular}

This table presents the distribution of banks with NSFR $\geq 1$ across 28 European countries during Subprime mortgage crisis, European sovereign crisis and on the overall period (2001-2013). The first three columns show the total number of banks in our final sample, the average number of banks with NSFR $\geq 1$ and the ratio of these banks' total assets to the overall banking sector total assets in the country. Columns 4 \& 5 depict the number of banks with their NSFR $\geq 1$ and the ratio of their relative assets size to the overall banking sector total assets in the country during the subprime crisis. Columns $6 \& 7$ represent the number of banks with their NSFR $\geq 1$ and the ratio of their relative assets size to the overall banking sector total assets in the country during the sovereign crisis. 
Table A5: Descriptive Statistics on the subsamples of SIFIs.

\begin{tabular}{|l|rrrrr|}
\hline Stats & \multicolumn{1}{|l}{ Mean } & \multicolumn{1}{l}{ Sd } & \multicolumn{1}{l}{ Min } & \multicolumn{1}{l|}{ Median } & \multicolumn{1}{c|}{ Max } \\
\hline NSFR & 0.731 & 0.410 & 0.008 & 0.803 & 2.000 \\
Size (1000 $€$ ) & $3.88 \mathrm{E}+08$ & $4.99 \mathrm{E}+08$ & 277451.4 & $1.75 \mathrm{E}+08$ & $2.20 \mathrm{E}+09$ \\
Net-Lending- & $-1.26 \mathrm{E}+07$ & $3.09 \mathrm{E}+07$ & $-1.67 \mathrm{E}+08$ & -4051900 & $6.51 \mathrm{E}+07$ \\
Position & & & & & \\
InDegree & 10.114 & 11.544 & 0 & 5 & 55 \\
OutDegree & 9.267 & 9.814 & 0 & 6 & 53 \\
Closeness & 0.378 & 0.165 & 0 & 0.348 & 1 \\
Betweenness & 0.234 & 0.264 & 0 & 0.127 & 1 \\
Authority & 0.060 & 0.078 & 0 & 0.032 & 0.444 \\
Hub & 0.056 & 0.072 & 0 & 0.029 & 0.36 \\
ClusteringCo & 0.065 & 0.132 & 0 & 0.018 & 1 \\
PageRank & 0.076 & 0.102 & 0.0008 & 0.036 & 0.468 \\
\hline
\end{tabular}

This table presents the descriptive statistics on the subsample of SIFIs on the period 2001-2013; NSFR= Net Stable Funding Ratio; Size = SIFI total assets; Network variables= InDegree, OutDegree, ClusteringCo, Hub, Authority, Betweenness, Closeness, PageRank;Net lending position= (interbank lending - interbank borrowing). All dependent and bank-level control variables are winsorized at $5 \%-95 \%$ except the network variables. 
Table A6: G-SIBs as of November 2015 allocated to buckets corresponding to required level of additional loss absorbency

\begin{tabular}{|c|c|}
\hline Bucket & $\begin{array}{l}\text { G-SIBs in alphabetical order within each } \\
\text { bucket }\end{array}$ \\
\hline $5-(3.5 \%)$ & (Empty) \\
\hline $4-(2.5 \%)$ & $\begin{array}{l}\text { HSBC } \\
\text { JP Morgan Chase }\end{array}$ \\
\hline $3-(2.0 \%)$ & $\begin{array}{l}\text { Barclays } \\
\text { BNP Paribas } \\
\text { Citigroup } \\
\text { Deutsche Bank }\end{array}$ \\
\hline $2-(1.5 \%)$ & $\begin{array}{l}\text { Bank of America } \\
\text { Credit Suisse } \\
\text { Goldman Sachs } \\
\text { Mitsubishi UFJ FG } \\
\text { Morgan Stanley } \\
\end{array}$ \\
\hline 1- $(1.0 \%)$ & $\begin{array}{l}\text { Agricultural Bank of China } \\
\text { Bank of China } \\
\text { Bank of New York Mellon } \\
\text { China Construction Bank } \\
\text { Groupe BPCE } \\
\text { Groupe Crédit Agricole } \\
\text { Industrial and Commercial Bank of China } \\
\text { Limited } \\
\text { ING Bank } \\
\text { Mizuho FG } \\
\text { Nordea } \\
\text { Royal Bank of Scotland } \\
\text { Santander } \\
\text { Société Générale } \\
\text { Standard Chartered } \\
\text { State Street } \\
\text { Sumitomo Mitsui FG } \\
\text { UBS } \\
\text { Unicredit Group } \\
\text { Wells Fargo }\end{array}$ \\
\hline
\end{tabular}

The bucket approach is defined in Table 2 of the Basel Committee Document Global systemically important banks: updated assessment methodology and the higher loss absorbency requirement, July 2013. The numbers in parentheses are the required level of additional common equity loss absorbency as a percentage of risk-weighted assets that applies to each G-SIB, starting from those identified from November 2014, with phase-in starting in January 2016. Based on the implementation schedule, GSIBs identified in November 2015 will be required to hold in $201750 \%$ of the higher loss absorbency applying to the bucket of systemic importance to which they have been allocated in the list published in November 2015. 